\title{
RISK MANAGEMENT OF PORTFOLIO SECURITIES
}

\author{
Milena Jaksic* \\ Faculty of Economics, University of Kragujevac, Kragujevac, Serbia
}

\begin{abstract}
Investment funds in different types of financial assets are motivated by investors' expectation to realize a profit. Since the expected return is not always certain, the investor is faced with a risk of his investment not giving results in accordance with the expectations. Therefore, the consideration of risk by which the concrete placement is hampered should not be neglected or left to intuition. An incorrect risk assessment can result in a lack of the expected return or a loss of a capital investment. The global financial crisis has indicated on the possible absence consequences of the comprehensive risk management, in other words, the inadequate perceiving of all the risks and their interdependencies. In this paper, the system of managing risks including their early identification, assessment, measuring and risk control is analyzed. At the same time, models providing an effective portfolio diversification in the function of reducing an investment risk have been analyzed. It is indicated that risk management requires the process flexibility without strongly relying only on mathematical models that failed to identify the growth of a systemic risk.
\end{abstract}

Keywords: risk management, diversification, portfolio, systemic risk

JEL Classification: G11, G22

\section{INTRODUCTION}

In the second half of $X X$ century, the financial sector went through numerous changes that influenced the change of the institutional structure of the functioning of the financial system. This contributed to the expansion to the scope of the activities carried out by financial institutions, as well as to an increase in investors' exposure to numerous risks of imminent financial activities. Therefore, it is necessary to identify and analyze the changes that dynamically developed thanks to the globalization of financial flows, deregulation, financial innovation and information

\footnotetext{
* Correspondence to: M. Jaksic, Faculty of Economics, University of Kragujevac, Dj. Pucara 3, 34000 Kragujevac, Serbia; e-mail:milenaj@kg.ac.rs
}

technology. The effort is focused on the fact that, under certain conditions, regularities in the emergence and development of a certain financial phenomenon can be detected. In order to reduce possibilities for the development of a new financial-system crisis, it is necessary to perform the activity of improving the risk management process in financial flows.

Although the existence of risk has always been in conflict with a man's aspirations to pursuing civilizational progress, without the presence of risk the progress would be lagging or would significantly be slower. The economic reality of modern market economies confirms the emergence of new risks as well as the modification of the existing ones. The ability to identify potential risks, quantify them, identify the consequences and take appropriate strategies is what 
makes the modern financial sector different from the financial sector in the past. Although risk-taking always was closely related to the basic activities of financial institutions at the end of the 1980's, financial institutions did not have an independent function of risk management, nor was the risk management concept widely known.

Considering the above-mentioned, the case study will be focused on the study of the alternative approaches to managing risks in financial flows. The aim of the research is to perform an overall analysis of the risk management of portfolio securities using modern portfolio theory. The key hypothesis which the paper is based on begins as follows: if a set of securities are given within the selection that can be made, the portfolio theory provides an opportunity for an investor to decide which combination of securities produces the highest return for the given level of risk. Taking into account the complexity of these issues, a set of methodological procedures and techniques will be used to allow the testing of the established hypothesis in the research process. The result of the applied research will be the understanding of individual situations, i.e. the case that is being investigated, by comparing the selected relevant indicators that are being studied.

Taking into account the defined subject, the aim and the hypothesis expressed in the paper, first, the concept of risk in financial business will be introduced. Then different approaches of managing risks in modern financial flows will be analyzed. In order to improve the risk management process in the focus of the analysis, the portfolio risk of securities will be measured. Since the accuracy of constructing an optimal portfolio depends on a degree of the compliance of the characteristics of the real environment with the accomplished assumptions, the purpose of such an analysis is to determine whether it is possible to reliably apply modern portfolio theory in a real environment.

\section{REVIEW OF PREVIOUS RESEARCH}

The growth of the financial market instability and an increase in systematic risks caused risk management in financial business to represent one of the most researched areas in financial flows today. One of the first attempts to understand the trade-off of risk and an expected return belongs to Markowitz (1952). Studies have shown that, by portfolio diversification, one can construct a portfolio with the best performances. Also, by a gradual diversification, an unsystematic risk can be eliminated, while the remaining systemic risk shows that the return of almost every security depends on the performance of a market and uncertainties related to general economic trends. The researches done on different share markets have shown that on average $50 \%$ of the risk is eliminated by unexpectedly forming the selected portfolio of five to ten shares (Whitmore, 1970). The same research showed that the portfolio risk cannot significantly be reduced by increasing the number of shares from ten to more. Also, studies conducted by McEnally and Boardman (1979) refer to the bond market, suggesting that the impact of a diversified bond portfolio is highly correlated with findings related to the ordinary market share.

A contribution to the portfolio theory was made by Sharpe (1964), who developed a capital asset pricing model (Capital Asset Pricing Model, CAPM) and Ross (1976), who formed an arbitrage pricing model (Arbitrage Pricing Theory, APT). These models represent a base to assess the value of securities under conditions of the existing equilibrium in the financial market. The models are developed on certain assumptions which the market economy conditions simplified. Therefore, a significant number of required input data for portfolio selection are reduced, as well as their limited applicability in the current economic conditions. Certainly, the most important lack of modern portfolio theory is its ignoring the fact that, during the crisis, correlation coefficients tend to unite, so the benefits of diversification disappear (Fabozzi \& Modigliani, 1996). In response to the increasing number and intensity of risk in terms of methodology, the value-at-risk method (Value at Risk, VaR) represents a natural progression of the portfolio theory (Beder, 1995). VaR expresses risk as the maximum possible loss of a portfolio due to adverse market trends during the defined time for a given probability, assuming that such a portfolio is not managed during the period (Hull, 2010). The application quality of this model is that, with a certain level of statistical confidence, the represented value at risk will not be lost in the defined time horizon. 
However, it should be noted that the application of $\mathrm{VaR}$ in practice has a number of significant limitations related to the existence of the assumptions of the normality and stationary distribution of return series (Kim \& Finger, 2000).

In terms of the original methodology by Markovic, all known portfolio models have until now been characterized by portfolio diversification and optimal portfolio construction (Back, 2010). Although in the theoretical models there is an assumption that diversification is the best choice in practice, it is not the case. Namely, in order to understand the possibilities of diversification, as a strategy of action, researching it has revealed that average results are generated by diversification (Semmler, 2011). In that way, diversification corresponds to those investors in the financial market who cannot reliably estimate trends in the future, as well as those who have an aversion to risk (Rubinstein, 2002).

\section{CONCEPT OF RISK IN FINANCIAL MANAGEMENT}

In terms of globalization, the deregulation and intense development and application of information technology correlates with the growth and interdependence of financial flows. Correlation and interdependence are assumptions of positive and negative synergies (Đuričin, 2009). Theoretical arguments in favor of interdependence are based on the fundamental theorem of welfare economics (competition in the market provides a Pareto optimality) and the theory of an efficient financial market (all pieces of information on the financial market are immediately and fully incorporated in decisions made by market participants) (Eatwell, 1996). On the other hand, a moral hazard is a negative phenomenon easily convertible into turbulence difficult to predict. The economy of moral hazard creates an imbalance between the created value in the real sector and issued values in the financial sector. The stated imbalance forms a "speculative bubble" - once it bursts, the economy of moral hazard ceases to exist; however, the bursting of such a "speculative bubble" causes a crisis inducing a cascading effect expanding to the global economy. The mentioned imbalance forms a "speculative bubble" which, when it bursts, makes the economy of moral hazard cease to exist; however, the bursting of such a speculative bubble causes a crisis inducing a cascading effect expanding to the level of the global economy.

In a global environment, risk becomes an inseparable component of the economic activities of participants in the real and financial sectors. Risk is associated with an uncertainty in the realization of future outcomes. In a broader sense, risk represents a possibility of the occurrence of an unexpected event which can lastingly affect its objectives. Simultaneously, consequences can be both positive and negative. However, in a narrow sense, risk represents a chance for an adverse event to occur. This is a situation where there is a real possibility of a negative deviation from a desired outcome, in other words, the realization of risk will negatively affect the achievement of defined goals.

The probability of an actual deviation of a desired outcome is the key determinant in defining risk. Investors tend to achieve high returns on their investments; however, the majority of them have an aversion to risk. Risks reduce the marginal utility

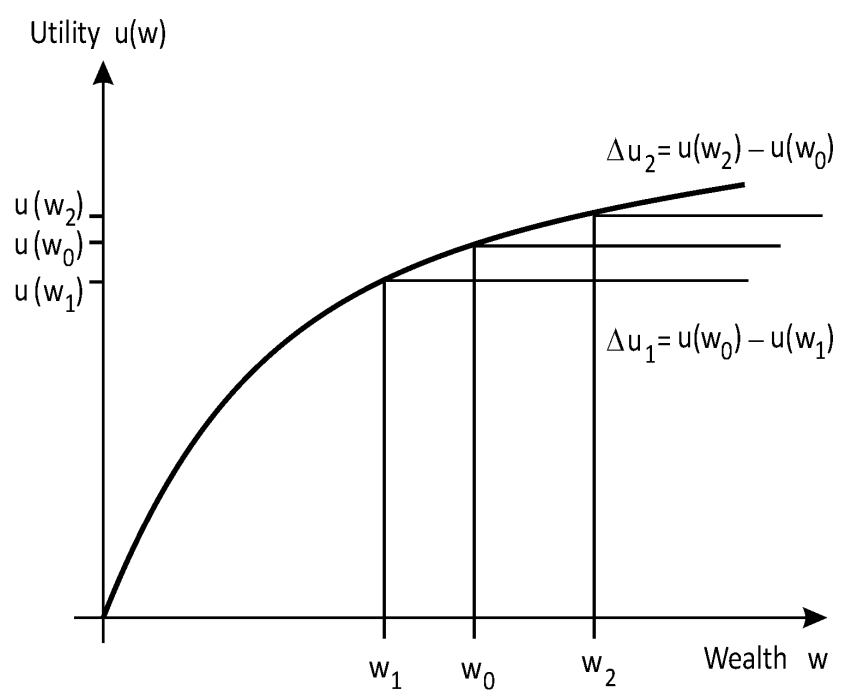

Figure 1 Concave utility function

Source: Barucci, 2003, 21 
of wealth, because the function of utility is concave in relation to wealth (Figure 1). The additional or marginal growth of wealth increases usefulness for successively smaller amounts, so that investors with a concave utility function have a decreased marginal utility of wealth. For any level of wealth, the given decline of wealth leads to a larger decrease in utility than the same increase in wealth leads to an increase in utility.

As can be seen, the utility level i.e. satisfaction grows less and less as wealth increases. The initial level of wealth wo implies the usefulness level from $\mathrm{u}\left(\mathrm{w}_{0}\right)$. If wealth decreases by the amount of $\Delta \mathrm{w}_{1}=\mathrm{w}_{0}-\mathrm{w}_{1}$, utility decreases by the amount of $\Delta \mathrm{u}_{1}=\mathrm{u}\left(\mathrm{w}_{0}\right)-\mathrm{u}\left(\mathrm{w}_{1}\right)$. On the other hand, if wealth increases by the same amount $\Delta \mathrm{w}_{2}=\mathrm{w}_{2}-\mathrm{w}_{0}$, utility increases by the amount of $\Delta \mathrm{u}_{2}=\mathrm{u}\left(\mathrm{w}_{2}\right)-\mathrm{u}\left(\mathrm{w}_{0}\right)$. When marginal utility is reduced, $\Delta \mathrm{u}_{1}$ is always higher than $\Delta \mathrm{u}_{2}$.

Rational investors, who have an aversion to risk, will not choose a risky investment offering the same expected return as well as an investment free from risk. In fact, they are not willing to accept additional risk not compensated for by an additional return (risk premium). On the other hand, investors neutral to risk have a linear utility function showing the constant marginal utility of wealth and therefore will be indifferent to the choice of a risk-free or risky investment offering the same expected return. For these investors, $\Delta \mathrm{u}_{1}=\Delta \mathrm{u}_{2}$. Finally, investors accepting risk have a convex utility function showing an increasing marginal utility of wealth. Therefore, they will prefer risky investments, because in this case $\Delta \mathrm{u}_{2}>\Delta \mathrm{u}_{1}$.

Considering the above-mentioned, it should be noted that, in the last three decades, risk has been underestimated and/or passed on to others. This resulted in the change in the strategy towards risk in terms that investors' strategies highly denying being at risk evolved into strategies characterized by a high-risk liability. It is obvious that under conditions of the global financial crisis and the recession, a ratio towards risk must change. Avoiding risks in terms of performing a low-level economic activity is not desirable. What is needed is managing risk, but in an intelligent way that contributes to value creation (Đuričin, 2009).
RISK MANAGEMENT PROCESS IN FINANCIAL TRANSACTIONS

Risk management is an integral part of the management activities in all sectors. It is a concept involving a set of coordinated activities of the management and controlling the organization in terms of risk (PD ISO/IEC Guide 73:2002). In the changed management conditions, it is obvious that a new model of risk management based on the identification of potential risks is needed, as well as their assessment and measurement, recognizing the consequences and, based on that, taking adequate strategies, such as avoidance, transfer, prevention and retention or risk storage (Figure 2).

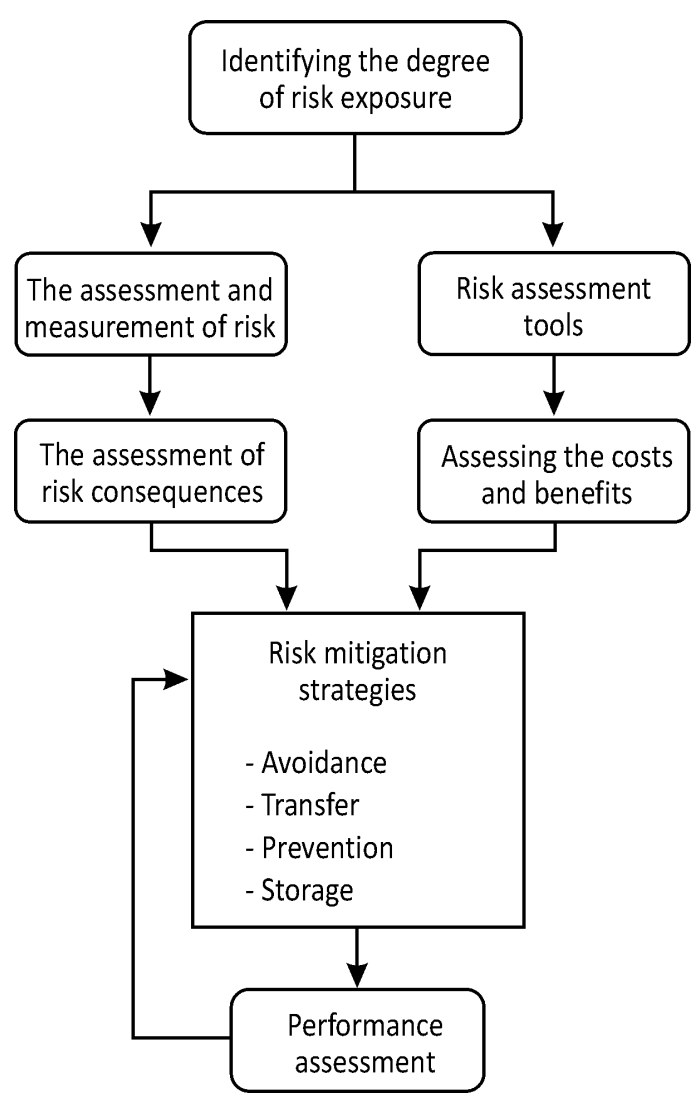

Figure 2 The proces of risk management

Source: Crouhy \& Robert, 2006, 2 
This seemingly simple range of the presented activities indicates that a continual process of risk management is in question. However, the risk management process should not be viewed merely as a process of defense against risk, because financial institutions choose the type and level of risk, the one acceptable for them to take. Most business decisions involve the sacrifice of the current return for the sake of future uncertain returns. Risk management and risk-taking are not contradictory activities, but they represent two sides of the same process. Exactly the expanded concept of risk management is not only based on the avoidance of risk, but also on the use of risk (Segal, 2008). In the conditions of a low level of the economic activity, it is necessary that risks be managed in a way that will contribute to the choice of strategies bringing the highest value for the acceptable level of risk.

Sometimes it is seemingly a simple process of identifying risk which is complex, because it is difficult to draw a clear line at a point where one risk ends and another one begins. The methodology for quantifying risk is also very complex. Risk-quantifying measures are numerous and depend on the type of risk we want to assess. To quantify risks, the following ones are commonly used: the variance and standard deviation, the assessment of the net present value, the internal rate of return, the assessment of the invested capital, arbitration evaluation as well as the value at risk (Hull, 2010).

After quantifying risk and identifying the consequences, we step into a complex phase concerned with the selection approaches and instruments for risk management. Risks not compensated for by the desired return of a financial institution are avoided. That can be achieved by selling financial assets charged with this type of risk (for example, by securitization placement and/or entering into hedging transactions). The advantage of this method is that the risk emergence of an economic event loss disappears or is significantly reduced. However, it also has several disadvantages. As one of the disadvantages it states the inability to avoid all risks which a company is exposed to. Another disadvantage is the fact that risk-related activities, by the rule, are profitable, so opportunity costs are high.

Risk transfer involves the transfer of risk, which the financial institutions are exposed to, to the market participants willing to take risk. It is usually realized by purchasing insurance, marketing and receivables purchase on the spot market and entering into transactions on the futures market. Some risks are consciously taken over by financial institutions. These are risks resulting from necessary daily activities, and are subject to moral hazard or those where there is no way to neutralize risk. When a decision is made on taking a certain risk, it is necessary that procedures for further risk management should be defined. One of the proven effective ways to manage risk is the diversification of investments by decreasing the frequency of both good and bad outcomes, which reduces a probable occurrence of a loss.

If investment diversification is impossible to accomplish, sometimes it is cheaper to establish a risk pool than pay insurance (Schroeck, 2002). If any of these risk management instruments are impossible to apply, it is resorted to hold the required capital depending on the projection of an unexpected loss, and serves to cover the expected loss (Hull, 2010).

For low-intensity high-occurrence-probability risks, the prevention and reduction of risk is recommended, while in the case of high-intensity high-occurrenceprobability risks, the risk-avoidance method is recommended. On the other hand, if the probability of occurrence is low and a risk is high, the method including the use of insurance is recommended, whereas in the case of low-intensity low-occurrence probability risks, risk-retention is recommended (Rejda, 2008).

\section{REQUIREMENT OF RETURN AND RISK}

As it is well-known, the presence of risk does not prevent investors from investing their available resources in different types of financial assets. However, the presence of risk affects investors' expectations concerning future returns. In contrast to risk-free assets where return is certainly well-known, in the case of risky assets, a return an investor needs to accomplish is highly uncertain. Therefore, when investing in risky assets, a potential investor has certain expectations about the amount of the desired return his investment should generate. Such an expected 
level of return represents a minimum below which an investor is not willing to invest his financial assets. A possibility of achieving a lower rate of return than the expected does a concrete risky investment. Standard investors' behavior means his expectation that he will realize a maximum return for an acceptable level of risk, regarding the minimal risk for a given level of return.

It is evident that investors who concentrate their wealth in one type of securities are rarely found. Because of the high transaction costs, a risk of an unexpected achievement loss increases . Instead, they tend to invest in a set of securities of different types and characteristics, in other words, they invest in a securities portfolio. In that way, the high risk of an expected return can be reduced, which depends both on the absolute risk of each investment in the portfolio and the relation between individual investments within the portfolio. In case a portfolio is made by investments among which there is a low-range correlation of the variation of the expected future returns, a portfolio risk can be expected to be less than the sum of individual risky investments.

If the variance or the standard deviation is high, the dispersion of future returns around the expected return is also higher, i.e. the investor is exposed to a greater uncertainty. While the standard deviation for individual securities is higher than the portfolio of securities, the average return in individual securities is lower than the return of the portfolio. The portfolio return is an average assessed return of individual securities making the portfolio and can be presented in the following way (Blake, 2000):

$r_{p}=\sum_{i=1}^{N} \theta_{i} r_{i}$

where:

$r_{p}$ - portfolio return,

$\mathrm{N}$ - the number of securities in the portfolio,

$r_{i}$ - return of i securities in the portfolio,

$\theta_{i}$ - participation of i securities in the portfolio, where

$$
\sum_{i=1}^{N} \theta_{i}=1
$$

Considering that the portfolio return $\left(\mathrm{t}_{1}\right)$ will be highly uncertain at some future period, in the present $\left(\mathrm{t}_{0}\right)$, the expected return of the portfolio is weighted an average return of the expected return of individual portfolio elements where the probability of possible outcomes, in other words, the expected return of the portfolio is expressed by the expected average return on the individual securities in all possible future scenarios, weighted by the probability that this scenario happens are used as weights:

$\bar{r}_{p}=\sum_{i=1}^{N} \theta_{i} \bar{r}_{i}$

where:

$\bar{r}_{p}=E\left(r_{p}\right)$ - the expected portfolio return,

$\overline{r_{i}}=E\left(r_{i}\right) \quad-$ the expected return of i securities in
the portfolio.

Using equations (1) and (2), the portfolio variance (or portfolio risk) is presented in the following way (Blake, 2000):

$$
\begin{aligned}
& \sigma_{p}^{2}=E\left(r_{p}-\bar{r}_{p}\right)^{2}=E\left[\sum_{i=1}^{N} \theta_{i}\left(r_{i}-\bar{r}_{i}\right)\right]^{2}= \\
& =\sum_{i=1}^{N} \sum_{j=1}^{N} \theta_{1} \theta_{j} \sigma_{i j}=\sum_{i=1}^{N} \sum_{j=1}^{N} \theta_{i} \theta_{j} \sigma_{i} \sigma_{j} \rho_{i j}
\end{aligned}
$$

where:

$\sigma_{p}^{2} \quad$ - the variance of the portfolio return,

$\sigma_{i i}=\sigma_{i}^{2}=E\left(r_{i}-\bar{r}_{i}\right)^{2}-$ the variance return of $\mathrm{i}$ securities,

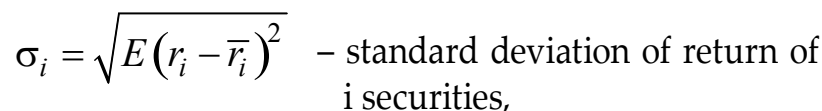
$\sigma_{i j}=E\left(r_{i}-\bar{r}_{i}\right)\left(r_{j}-\bar{r}_{j}\right) \quad$ - the covariance return of $i$ and $j$ securities,

$\rho_{i j}=\sigma_{i j} / \sigma_{i} \sigma_{j}$ - the correlation coefficient return of $i$ and $j$ securities.

In order to measure a portfolio risk, it is necessary to know not only the variance of the securities forming the portfolio, but the correlation of the expected return as well, in reference to the degree and directional movement of agreement from the expected returns of 


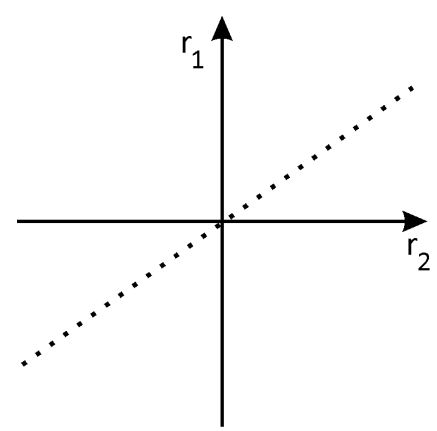

(a)

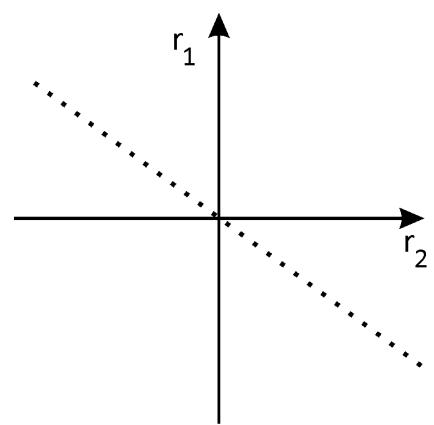

(b)

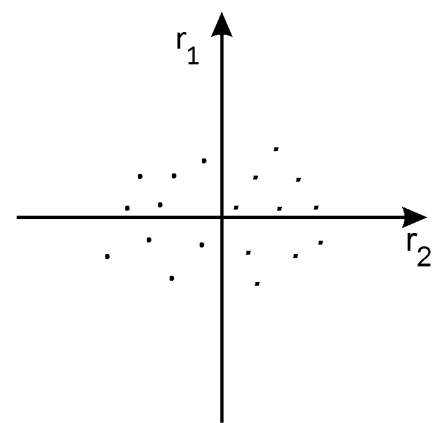

(c)

Figure 3 Returns on two securities: a) perfect (positive) correlation, b) perfect (negative) correlation,

c) the absence of a linear relationship

Source: Sharpe, Alexander \& Bailey, 1995, 180

each pair of securities from the portfolio. If returns on the two securities are perfectly (positively) correlated, then the correlation coefficient is +1 (Figure 3a). If returns on securities are perfectly (negatively) correlated, the correlation coefficient is -1 (Figure $3 b)$. When returns are uncorrelated, the correlation coefficient has the value of zero (Figure 3c). A rational investor who has an aversion to risk will perfectly choose negatively correlated returns, i.e. a risk-free portfolio (Sharpe, Alexander \& Bailey, 1995). If there is a weak connection between each pair of investments, then the portfolio risk can be expected to be lesser than the sum of individual risky investments in the portfolio. In general, the weaker the correlation between the securities the greater the impact of diversification on reducing variability.

An overall portfolio risk, i.e. the standard deviation of a portfolio, decreases with an increasing number of securities in the portfolio. Thus the threshold at which the total portfolio risk is reduced to the market or systemic risk is very low. Therefore the risk of a totally diversified portfolio depends on the market risk of securities included in the portfolio. The measure of systematic risk is $\beta$ coefficient. It measures the sensitivity of individual securities return to a change in the market return portfolio. If a market index rises, the value of particular securities, regardless of a diversification degree, will have an increasing trend. If the market index is declining, the actual value of securities will be decreasing as well. The beta coefficient is a linear measure of that relation (Figure 4).

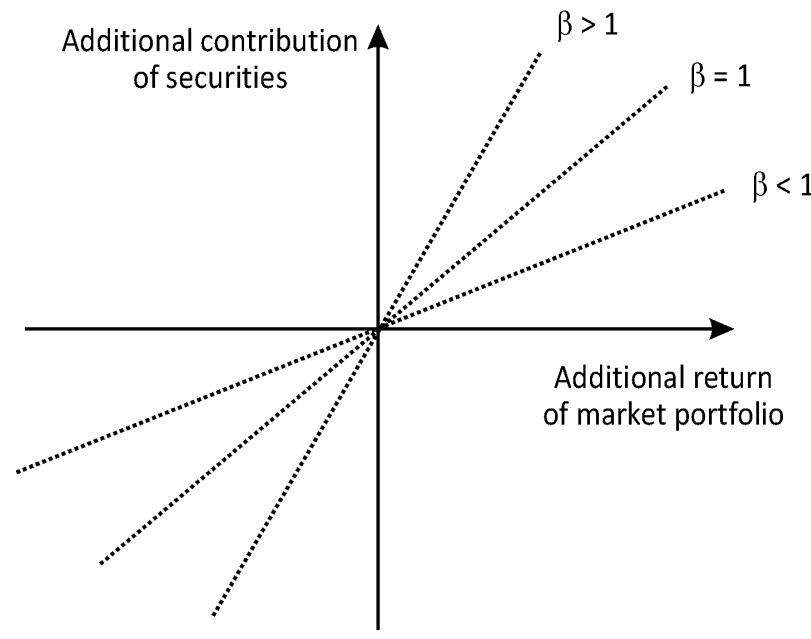

Figure 4 The characteristic line with different $\beta$ coefficient

Source: Van Horne \& Wachowicz, 1998, 101 
If there is a direct proportionality between a return of individual securities and a market portfolio return, the value of the beta coefficient is one $(\beta=1)$. The return rate of securities will fluctuate in a long term in the same direction and degree as well as the rate of return on the market portfolio. In the case when the value of the beta coefficient is higher than one $(\beta>1)$, a change in the rate of a return on securities is higher than a change in the market portfolio (aggressive investment). In the case when the value of the beta coefficient is less than one $(\beta<1)$, the investment promises a lower return from an additional return of a market portfolio (defensive assets).

The beta coefficient of the individual investments in the securities portfolio determines the risk level of that portfolio. The beta coefficient of a portfolio is determined as the weighted mean of the beta coefficient by individual members of the portfolio. The percentage share of investments in a portfolio is commonly used as a weight. The mathematical statement of the stated is (Fabozzi \& Modigliani, 1996):

$\beta_{p}=\sum_{i=1}^{n} W_{i} \beta_{i}$

where:

$\beta_{p}$ - the beta coefficient of a portfolio,

$\beta_{i}$ - the beta coefficient of i portfolio member,

$W_{i}$ - part of the total investment in a portfolio invested in i portfolio member.

Reading the stated formula based on (4), we may conclude that the beta coefficient portfolio represents a weighted average of the individual beta coefficients of the securities from the portfolio, where the shares of the total market value of the portfolio presented by each security are weighted. Numerous organizations regularly publish calculated beta coefficients for shares which are the subject of active trading. Although this concept is not free from deficiencies, it represents an acceptable and frequently used base for quantifying the systemic risk of an individual securities or portfolios as a whole.

The systemic risk $\left(\mathrm{S}_{\mathrm{r}}\right)$ of securities represents a product of the beta coefficient and the standard deviation of the market return $\left(\operatorname{std}\left(\mathrm{R}_{\mathrm{M}}\right)\right)$ :
$\mathrm{S}_{\mathrm{r}}=\beta \operatorname{std}\left(\mathrm{R}_{\mathrm{M}}\right)$

Analogically to the previous one, if the systemic risk of individual securities is given, then the systemic risk portfolio can be calculated $\left(\mathrm{S}_{\mathrm{rp}}\right)$ :

$S_{\mathrm{rp}}=\beta_{\mathrm{p}} \operatorname{std}\left(\mathrm{R}_{\mathrm{M}}\right)$

It can be concluded that the main purpose of quantifying both systemic and unsystematic risks calculate the overall portfolio risk. A large part of the total risk can be eliminated by diversification. As long as the greater part of the total risk can be eliminated by diversification, there is no economic demand that the realized return be tied to an overall risk. Instead, the realized return can be expected to be associated with a part of risk which cannot be eliminated (systemic risk).

\section{SELECTION OF PORTFOLIO WITH THE BEST CHARACTERISTICS}

Combining different securities available on the market, it is possible to get a large number of portfolios. However, all possible combinations have their border distribution. Since the financial market investor has a possibility of combining a large number of securities, the limit distribution has the form shown in Figure 5. A set of possible portfolios is shown as a shaded area AHBQ. This set of portfolio satisfies the assumption that investors have perfect and homogeneous expectations regarding a future return of securities.

It should be noted that not every portfolio in the set of portfolio possibilities is interesting for consideration. For example, it is the case with the portfolios over which other portfolios clearly dominate. One portfolio will dominate over another if it has a lower standard deviation for the same expected return, or a larger return for the same standard deviation. Portfolios dominated by other portfolios are known as inefficient portfolios in the financial theory. All portfolios within the set of portfolio possibilities (such as $\mathrm{P}_{1}, \mathrm{P}_{2}, \mathrm{P}_{3}$ ) are those dominated by the portfolio on the left side of the portfolio border. This left border is known as the set of portfolio possibilities with a minimum standard 
deviation. All portfolios located on the border distribution of the HA satisfy the condition for the given level of the expected return and have the lowest standard deviation. These are efficient portfolios, and their set makes a set of efficient portfolios representing a part of the set portfolio possibilities with a minimum standard deviation that does not contain inefficient portfolios.

The question is what happens if in the efficient set - apart from risky securities - there are risk-free securities, whereby these risk-free securities can be borrowed at a single risk-free rate of return. Initially, a portfolio consisting of only one risky security is analyzed $\left(\mathrm{x}_{1}\right)$ and one risk-free securities $\left(\mathrm{x}_{\mathrm{f}}\right)$. The expected return of the portfolio is (Blake, 2000):

$\bar{r}_{p}=\theta_{1} \bar{r}_{i}+\theta_{2} \bar{r}_{f}$

where:

$\bar{r}_{f}$ - the risk free rate of return,

$\theta_{1}$ - the proportion of wealth contained in the risky securities value, $\theta_{2}=1-\theta_{1}$

The standard deviation of the portfolio is:

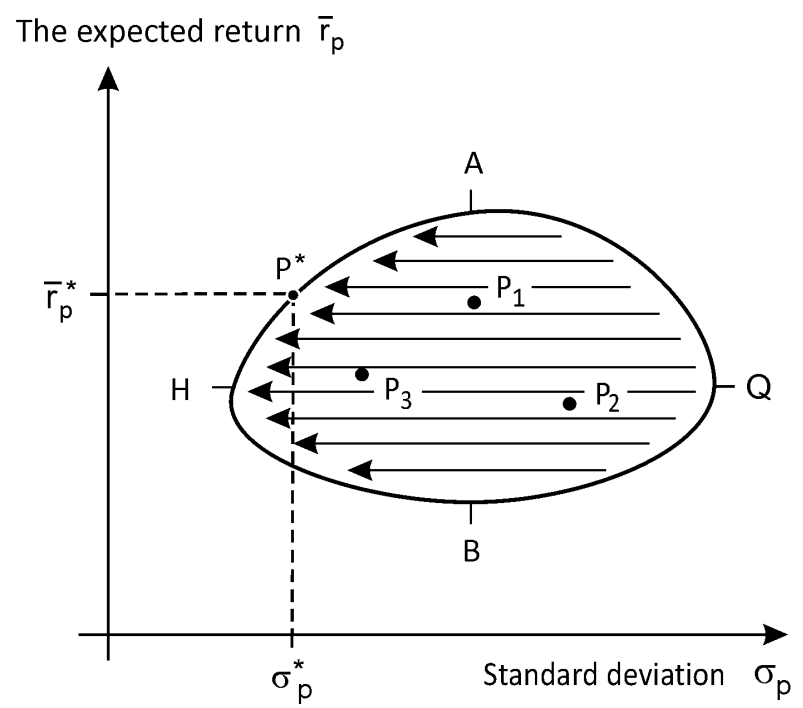

Figure 5 Feasible and efficient set

Source: Blake, 2000, 475 $\sigma_{\mathrm{p}}=\theta_{1} \sigma_{1}$

which results from the definition saying that the risk-free rate of return has a zero variance $\left(\sigma_{f}^{2}=0\right)$ and is not correlated with the return of risky assets $\left(\sigma_{1 f}=0\right)$. Equations (7) and (8) give a linear set of portfolio possibilities. At point $C$, the investor forms a portfolio by investing in risk-free assets (return on the portfolio is rf and the portfolio risk is zero). At point M (Figure 6), the investor forms a portfolio by offering funds in risky investments, with an expected return $r_{i}$ and an expected risk $\sigma_{i}$. At any point located between $\mathrm{C}$ and $\mathrm{M}$, part of the portfolio makes a risky investment (that is, $0<\theta_{1}<1$ ), and another part makes risk-free investments.

By finding a set of portfolio possibilities for riskfree investments and one risky investment, a set of portfolio possibilities and an efficient set can be found when a risk-free investment is combined with a risky investment (Figure 6). For example, when a risk-free investment is combined with a risky portfolio $\mathrm{K}$, a set of portfolio possibilities forms CKP. Similarly, when a risk-free investment is combined with a risky portfolio A, a set of portfolio possibilities CAJ is created.

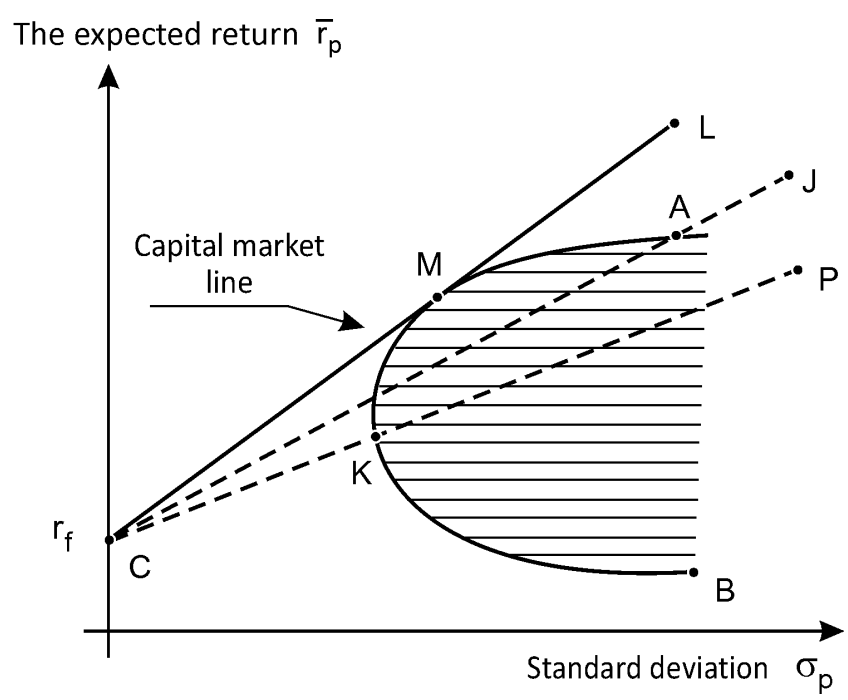

Figure 6 The set of portfolios with risk-free assets Source: Blake, 2000, 477 
This set of portfolio possibilities dominates over the CKP, for each portfolio on the line of the CAJ has a higher expected return than any portfolio in line CKP, with the same standard deviation. The set of portfolio possibilities which are not dominated by any other, there is the one resulting from combining a risk-free asset with a risky portfolio. In Figure 6, portfolio $\mathrm{M}$ is one lying at the tangent point between a segment line CML and the convex sets of the AMKB risky portfolio. When there is a risk-free asset that can be borrowed or given at the same risk-free rate, an efficient set includes all portfolios made of the combination of risk-free investments and risky portfolio $\mathrm{M}$. It implies that an effective set on the segment line is the CML. The slope coefficient of the effective border portfolio CML represents the market price of risk indicative of how much an additional return, above the risk-free return, the investors demand to expose the unit of the additional risk:

The market price of risk $=\frac{\overline{r_{m}}-r_{f}}{\sigma_{m}}$

where:

$\bar{r}_{m}$ - the expected return of portfolio $\mathrm{m}$,

$\sigma_{m}-$ standard deviation of portfolio $\mathrm{m}$.

The equation measures a necessary increase in the return that will compensate the investor for an additional unit of risk. It can clearly be seen in the case the equation of the capital market line is considered (Capital Market Line-CML):

$$
\bar{r}_{p}=r_{f}\left(\frac{r_{m}-r_{f}}{\sigma_{m}}\right) \sigma_{p}
$$

where:

$\bar{r}_{p}$ - the expected portfolio return line CML, $\sigma_{p}-$ standard portfolio deviation line CML.

As long as there are homogeneous expectations regarding risk and return, each investor will agree with the fact that the market price of risk is, at the same time, the marginal rate of risk transformation and return and that all effective portfolios will be evaluated in balance according to the previous equation. In other words, the rate of return required in order for an efficient portfolio to be in equilibrium will be given by $\bar{r}_{p}$ if its level of risk is given by $\sigma_{\mathrm{p}}$.

Each investor's optimal portfolio will be formed through the combination of the market portfolio and risk-free securities. The exact combination of the market portfolio and risk-free securities depends on the degree of an aversion towards risk. Namely, the optimal portfolio is determined by the point at which the indifference curve is tangent on the CML (Figure 7). At this point, the slope of the indifference curve (which measures the marginal rate of the substitution risk and return) is equal to the slope of the CML (which measures the marginal transformation rate of risk and return:

$$
M R S_{1}=M R S_{2}=M R T=\frac{\bar{r}_{m}-r_{f}}{\sigma_{m}}
$$

where:

$\mathrm{MRS}_{1}$ - the marginal rate of the substitution of risks and returns,

$\mathrm{MRT}_{1}$ - the marginal rate of transformation of risks and return (the market price of risk).

The equation is the standard optimality condition in an economy and can be used to calculate the proportions of the market portfolio and risk-free securities in the optimal portfolio. Because of the homogeneity expectations in the construction portfolio, investors will not make their specific combinations of the available securities. Each investor will construct a portfolio that is the same as the optimal portfolio, and will do so taking into consideration his own funds.

Considering the previously said, a conclusion can clearly be made, i.e. the starting hypothesis can be confirmed, if a set of securities within which a choice can be made is given, the portfolio theory provides an opportunity for the investor to decide which combination of securities results in the highest return for the given risk. 


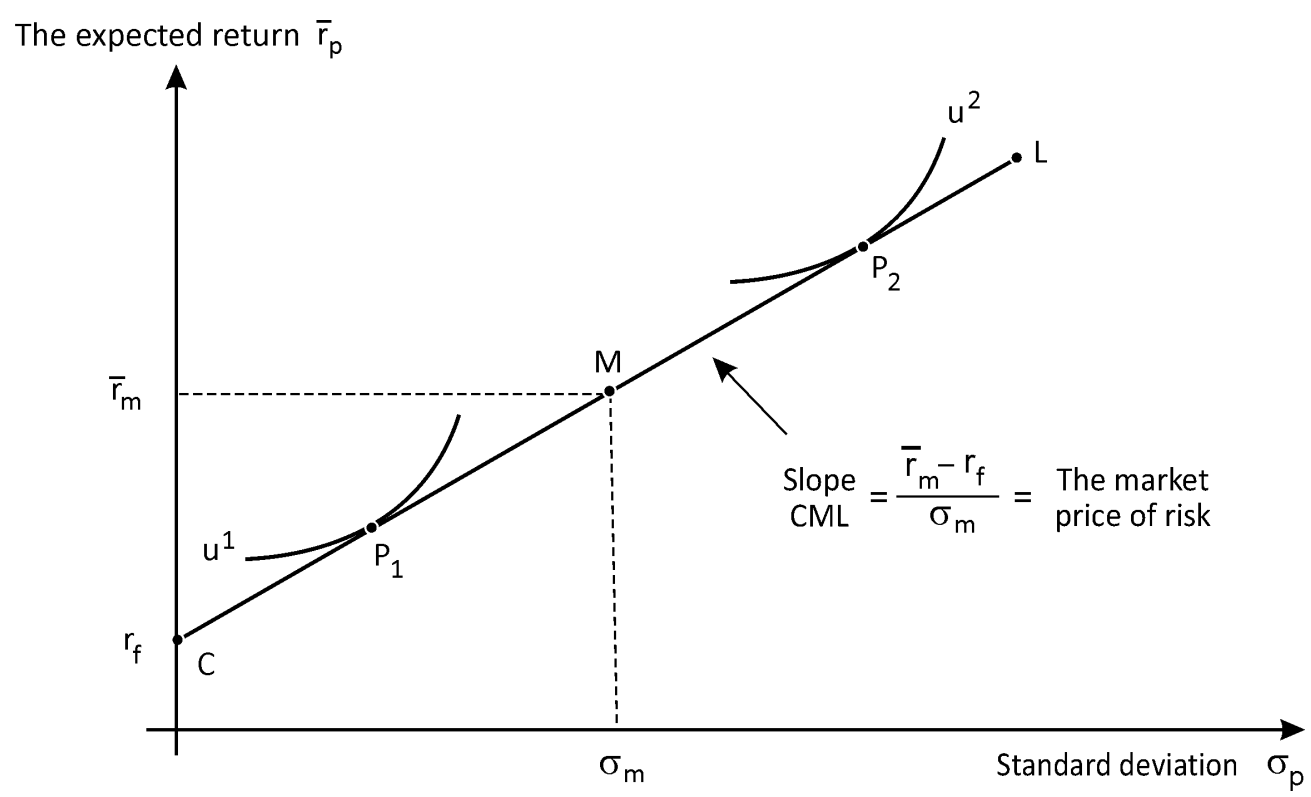

Figure 7 Optimal portfolio and market price of the risk

Source: Blake, 2000, 480

\section{A CRITIQUE OF MODERN PORTFOLIO THEORY}

The main idea which modern portfolio theory is based on is that the selection of securities for a portfolio is not based on the desired performance of securities. Modern portfolio theory has shown that a portfolio with the maximum expected return does not have to be the best alternative when risk is also included in the analysis. If investors make an effort to reduce the portfolio risk, it is not enough to invest in different securities; however, it is necessary that they should invest in securities with a high covariance. In that way, investors are enabled to form a set of efficient portfolios dominating over the set of all possible combinations of available securities. Each portfolio situated on the efficiency frontier includes an efficient exchange between the return and risk. In other words, the overall risk which the efficient portfolio is burdened with will be compensated for at a recognized market price by unit of risk.

Portfolio theory has shown that, instead of a random selection and random outcomes, there are both an optimal selection and outcomes as well. This is the optimal portfolio which is in the tangency point of the indifference curve on the efficiency frontier. The investor is indifferent in selecting any combination of risk and the expected return on the same indifference curve. The portfolio on the efficiency frontier whose tangent is not the indifference curve does not represent the optimal portfolio because it does not lead to the maximum utility function of the investor. Therefore, what is considered to be an optimal portfolio for one investor does not have to be an optimal one for another.

The procedure of calculating the statistical measures of return dispersion in the model is accurate, but also a complex that the number of securities included in the portfolio increases. Also, the model assumes the onehundred-percent accuracy of the input parameters, which is not the case in practice. Michaud (1989) defined this problem as one of the much greater sophistication optimization of algorithms in relation to the quality of input parameters, i.e. forecasting. The problem of assessing the input parameters gains importance when taking into account that the assessment of input parameters - the expected return and risk - is 
performed on the basis of an average value of historical data. This concept rejects the multivariable nature of a problem, so the assessment of the expected return, variance and covariance is always accompanied by a certain error. In this regard, Konno and Yamazaki (1991) have suggested the use of the absolute deviation of random variables, by which linear programming is done instead of the quadratic one. According to them, the absolute deviation of a random variable is the expected absolute value of the difference value by the random variable and its mean value and represents a linear measure of risk consistent with a stochastic dominant order.

Chopra and Ziemba (1992) point out that the effect of maximizing the error for input parameters also depends on the investor's risk preferences. In the case of the higher risk propensity of an error in the mean values are significant from the errors in the variance and covariance, as in the case of an aversion towards the risk of errors in the assessment of the expected return, is approximate to the impact of errors in the assessment of the variance and covariance. The reason for this is that the investor who has an aversion to risk it more important to mini mize the portfolio risk rather than increase the expected return; thus there is an error in the assessment of the expected return of less significant than the errors in the assessment of portfolio variance. Independently from the degree of aversion towards risk is considered are considered to be the most significant errors of mean value, then the error in variance, while the errors in covariance have the least impact on the optimal portfolio (Tumminelo et al, 2007).

A model of optimal portfolio choice also ignores the liquidity factor. The consideration of liquidity constraints in the process of determining a set of efficient portfolios related to the classical limit of efficiency leads to a small increase in return and/or risk reduction.

Numerous studies (Back, 2010; Semmler, 2011; Chapados, 2011; Belka \& Schneider, 2011) show that the distribution of the return series of securities deviates from the planned distribution by the model assumptions. The presence of asymmetry and the absence of flattening in relation to the normal distribution suggest a conclusion that the expected rate of return and the variance are insufficient to perform portfolio optimization. The contribution of portfolio securities to the variance is mainly determined by the covariance of the observed securities and all other securities in the portfolio (Rubinstein, 2002).

Mandelbrot (1963) has pointed out that the historical price data and return are not permanent, so the statistical measures of the mean value take different values at different times. Large and immediate changes in the prices of securities frequently occur, and it is easier to describe stochastic models. The successive price changes of securities do not seem independent, but are reflected through the identified patterns, which is the basis of a technical analysis. The pattern is different from the normal distribution because it has a pointed tip, rounded "shoulders" and thickened edges.

\section{CONCLUSION}

The global financial crisis and the recession have highlighted a danger of using innovative financial solutions, a high financial leverage, failures in risk management in the financial sector and a growing connection between subjects in terms of an increased exposure to a systemic risk. It is obvious that in such an environment a new risk management model based on the early identification of all the risks and the study of their mutual influence are required, as well as the expanded concept of risk management based not only on avoiding risk but also on the use of it. In this regard, risk control has to be versatile. This basically creates a stable environment for business and a better use of the available capital.

Exposed positions are developed with an attempt to indicate the method of selecting the best alternative investment market. In this presentation, it was noted that a weak correlation of securities reduces risk without reducing the return. However, the growing integration of national markets simultaneously reduces possibilities for achieving the positive effects of portfolio diversification. 
By financial innovations and new approaches to risk management, investors try to reduce the risk and take advantage of opportunities being offered by the global financial market. An effective risk management system means to clearly define the strategy and risk management policies, as well as the carriers of the risk management system. It is necessary that business processes and procedures for identifying, assessing, measuring and controlling risk should be defined. Additionally, sophisticated models provide diversification of risk and the assessment of an adequate amount of capital financial institutions. However, one must not forget that models cannot be a substitute for the man. Therefore an early warning detection of weak signals, the production of alternative scenarios - in the case of applying the best scenarios, i.e. constructing other portfolios and in the case of selecting the optimal portfolio.

The aforementioned risk measurement models represent a stable and reliable description of reality. However, because of a continuous growth in the systemic risk, future studies will require an application of an expanded concept of risk management, which in addition to the conventional approach to risk management also includes the process of considering the interaction of various risks. The global financial crisis has shown that during the degree of assessment to the risk exposures there is not enough attention dedicated to quality dimension, i.e. organization, management, incentives, processes and people. That involves shifting attention from seeking technical weaknesses of the risk management model to increase flexibility in risk management, recognizing the importance of the psychological factor causing change in the behavior of market participants and a comprehensive approach to risk management. Undoubtedly, this would lead to an improvement of risk management in financial flows today.

\section{ACKNOWLEDGEMENTS}

This paper is a part of the interdisciplinary research Project No. 41010, financed by the Ministry of Science of the Republic of Serbia.

\section{REFERENCES}

Back, E. K. (2010). Asset Pricing and Portfolio Choice. New York, NY: Oxford University Press.

Barucci, E. (2003). Financial Markets Theory: Equilibrium, Efficiency and Information. London, UK: Springer Finance.

Beder, S. T. (1995). VaR: Seductive but Dangerous. Financial Analysts Journal, 51(5), 12-24.

Belke, A., \& Schneider, J. (2011). Portfolio Choice of Financial Investors and European Business Cycle Convergence: A Panel Analysis for EU Countries. Empirica, November, 1-22, DOI: 10.1007/s10663-011-9181-4.

Blake, D. (2000). Financial Market Analysis. Chichester, England: John Wiley \& Sons Ltd.

Chapados, N. (2011). Portfolio Choice Problems: An Introductory Survey of Single and Multiperiod Models. New York, NY: Springer.

Chopra, V. K., \& Ziemba, W. T. (1993). The Effect of Errors in Means, Variances and Covariances on Optimal Portfolio Choice. Journal of Portfolio Management, 19(2), 6-11.

Crouhy, M., \& Robert, N. (2006). The Essentials of Risk Management. New York, NY: McGraw-Hill.

Đuričin, D. (2009). Kako iz ekonomije moralnog hazarda preći u ekonomiju inteligentnog upravljanja rizicima: Slučaj Srbije. Ekonomika preduzeća, 7-8, 259-283.

Eatwell, J. (1996). International Capital Liberalisation, The Impact on World Development. CEPA Working Paper Series I, Working paper No. 1, Center for Economic Policy Analysis, $1-61$.

Fabozzi, F., \& Modigliani, F. (1996). Capital Markets - Institutions and Instruments. New Jersey, NJ: Prentice-Hall, Inc.

Hull, C.J. (2010): Risk Management and Financial Institutions. Boston, Massachusetts: Pearson Education, Inc.

Kim, J., \& Finger, C. C. (2000). A Stress Test to Incorporate Correlation Breakdown. Journal of Risk, 2(3), 5-19.

Konno, H., \& Yamazaki, H. (1991). Mean-absolute Deviation Portfolio Optimization Model and its Application to Tokyo Stock Market. Management Science, 37(5), 519-531.

Mandelbrot, B. (1963). The Variation of Certain Speculative Prices. The Journal of Business, 36(4), 394-419.

Markowitz, H. (1952). Portfolio Selections. Journal of Finance, 7(1), 77-91. 
McEnally, W. R., \& Boardman, M. C. (1979). Aspects of Corporate Bond Portfolio Diversification. Journale of Financial Research, 1(1), 27-36.

Michaud, R. O. (1989). The Markowitz Optimization Enigma: Is „Optimized” Optimal? Financial Analysis Journal, 45(1), $31-42$.

PD ISO/IEC Guide 73:2002. Risk Management Vocabulary. Guidelines for Use in Standards.

Rejda, E. G. (2008). Principal of Risk Management and Insurance. 10th Edition, Boston, Massachusetts: Pearson Education, Inc.

Ross, S. (1976). The Arbitrage Theory of Capital Asset Pricing. Journal of Economic Theory, 13(3), 341-360.

Rubinstein, M. (2002). Markowitz's Portfolio Selections: a fifty - year retrospective. Journal of Finance, 57(3), 1041-1045.

Schroeck, G. (2002). Risk Management and Value Creation in Financial Institutions. Chichester, England: John Wiley and Sons Ltd.
Segal, S. (2006). Value - Based Enterprise Risk Management: The Key to Unlocking ERM Potential. Corporate Finance Review, 10(4), 16-26.

Semmler, W. (2011). Asset Prices, Booms and Recessions. 3rd Edition, Berlin Heidelberg, Germany: Springer

Sharpe, F. W., Alexander, J.G., \& Bailey, J.V. (1995). Investments. Englewood Cliffs, New Jersey, NJ: Prentice-Hall, Inc.

Sharpe, W. (1964). Capital Assets Prices: A Theory of Market Equilibrium. Journal of Finance, 19(3), 425-442.

Tumminelo, M., Di Matteol, T., Aste, T., \& Mantegna, R.N. (2007). Correlation Based Networs of Equity Returns Sampled at Different Time Horizons. The European Physical Journal B, 55, 209-217, DOI: 10.1140/epjb/e2006-00414-4.

Van Horne, C. J., \& Wachowicz, M. J. (1998). Fundamentals of Financial Management. New Jersey, NJ: Prentice-Hall, Inc.

Whitmore, G. A. (1970). Diversification and the reduction of dispersion: a note. Journal of Financial and Quantitative Analysis, 5(2), 263-264.

Milena Jaksic is an assistant professor at the Faculty of Economics, University of Kragujevac, Kragujevac, Serbia. She teaches the following courses: Principles of Economics and Financial markets and financial instruments. She received her $\mathrm{PhD}$ in economics from the Faculty of Economics, University of Kragujevac, in the field of Capital markets. The key areas of her scientific research interests include financial systems and financial markets. 


\title{
UPRAVLJANJE RIZICIMA PORTFOLIJA HARTIJA OD VREDNOSTI
}

\author{
Milena Jakšić* \\ Ekonomski fakultet Univerziteta u Kragujevcu
}

\begin{abstract}
Ulaganje novčanih sredstava u različite oblike finansijske aktive motivisano je očekivanjem investitora da ostvari prinos. Budući da očekivani prinos nije uvek izvestan, investitor se suočava sa rizikom da njegovo ulaganje neće dati rezultate u skladu sa očekivanjima. Stoga, sagledavanje rizika kojim je opterećen konkretan plasman ne sme biti zanemareno ili prepušteno intuiciji. Pogrešne procene rizika za posledicu mogu imati izostanak očekivanog prinosa ili gubitak uloženog kapitala. Globalna finansijska kriza je ukazala na moguće posledice odsustva sveobuhvatnog upravljanja rizicima, odnosno, neadekvatnog uočavanja svih rizika i njihove međuzavisnosti. $\mathrm{U}$ radu se analizira sistem upravljanja rizicima koji podrazumeva rano identifikovanje, procenu, merenje i kontrolu rizika. Istovremeno, razmatraju se modeli koji obezbeđuju efikasnu diversifikaciju portfolija u funkciji smanjenja rizika investiranja. Ukazuje se na to da upravljanje rizicima zahteva fleksibilnost procesa bez krutog oslanjanja samo na matematičke modele, koji nisu uspeli da identifikuju rast sistemskog rizika.
\end{abstract}

Ključne reči: upravljanje rizicima, diversifikacija, portfolio, sistemski rizik

JEL Classification: G11, G22

\section{UVOD}

U drugoj polovini 20. veka finansijski sektor je prošao kroz brojne promene koje su uticale na izmenu institucionalne strukture funkcionisanja finansijskog sistema. To je doprinelo širenju obima aktivnosti finansijskih institucija, kao i povećanju izloženosti investitora brojnim rizicima imanentnim finansijskim aktivnostima. Stoga je potrebno identifikovati i analizirati promene koje su se dinamički razvijale zahvaljujući globalizaciji finansijskih tokova, deregulaciji, finansijskim inovacijama i informacionoj

\footnotetext{
* Korespondencija: M. Jakšić, Ekonomski fakultet Univerziteta u Kragujevcu, Đ. Pucara 3, 34000 Kragujevac, Srbija; e-mail: milenaj@kg.ac.rs
}

tehnologiji. Napor je usmeren na to da se, u određenim uslovima, uoče moguće pravilnosti u nastajanju i razvoju određenih finansijskih pojava. U cilju smanjenja mogućnosti za nastanak novih kriza finansijskog sistema neophodno je preduzimati aktivnosti unapređenja procesa upravljanja rizicima $u$ finansijskim tokovima.

Iako je postojanje rizika oduvek bilo u suprotnosti sa čovekovim težnjama civilizacijskom napretku, bez prisustva rizika napredak bi izostao ili bi bio znatno usporeniji. Ekonomska stvarnost savremenih tržišnih privreda potvrđuje kako pojavu novih rizika, tako i modifikaciju već postojećih rizika. Sposobnost identifikovanja potencijalnih rizika, njihovo kvantifikovanje, uočavanje posledica i preduzimanje 
adekvatnih strategija jeste ono po čemu se savremeni finansijski sektor razlikuje od finansijskog sektora $\mathrm{u}$ prošlosti. Iako je preuzimanje rizika uvek bilo usko povezano sa osnovnim aktivnostima finansijskih institucija sve do kraja osamdesetih godina 20. veka, finansijske institucije nisu imale nezavisne funkcije upravljanja rizicima, niti je koncept upravljanja rizicima bio široko poznat.

Imajući u vidu navedeno, predmet istraživanja biće usmeren na proučavanje alternativnih pristupa upravljanja rizicima u finansijskim tokovima. Cilj istraživanja je da se izvrši sveobuhvatna analiza upravljanja rizicima portfolija hartija od vrednosti primenom savremene portfolio teorije. Ključna hipoteza od koje se u radu polazi je: ukoliko je dat skup hartija od vrednosti u okviru kojeg se može napraviti izbor, portfolio teorija pruža mogućnost investitoru da odluči koja kombinacija hartija od vrednosti dajenajbolji prinos za dati nivo rizika. U procesu istraživanja, uvažavajući složenost navedene problematike, biće korišćen skup metodskih postupaka i tehnika koje će omogućiti testiranje postavljene hipoteze. Rezultat primenjenih istraživanja biće razumevanje pojedinačnih situacija, odnosno, predmeta koji se istražuje, kroz komparaciju izabranih relevantnih indikatora koji se proučavaju.

Vodeći računa o opredeljenom predmetu, ciljui hipotezi, $\mathrm{u}$ radu ce najpre biti predstavljen koncept rizika $\mathrm{u}$ finansijskom poslovanju. Zatim će biti analizirani različiti pristupi upravljanja rizicima u savremenim finansijskim tokovima. U cilju unapređenja procesa upravljanja rizicima, $\mathrm{u}$ fokusu analize biće merenje rizika portfolija hartija od vrednosti. Budući da tačnost konstruisanja optimalnog portfolija zavisi od stepena saglasnosti učinjenih pretpostavki sa karakteristikama realnog okruženja, namera ovako postavljene analize je da se utvrdi da li je u realnom okruženju, za potrebe merenja rizika, moguća pouzdana primena savremene portfolio teorije.

\section{PREGLED PRETHODNIH ISTRAŽIVANJA}

Rast nestabilnosti na finansijskim tržištima i povećanje sistemskog rizika uticali su na to da upravljanje rizicima (risk management) $\mathrm{u}$ finansijskom poslovanju predstavlja jednu od najčešće istraživanih oblasti u finansijskim tokovima današnjice.
Jedan od prvih pokušaja da se razume supstitabilnost (trade-off) rizika i očekivanog prinosa pripada Markowitz-u (1952). Istraživanja su pokazala da se diversifikacijom može konstruisati portfolio koji ima najbolje performanse. Takođe, diversifikacijom se postepeno može eliminisati nesistemski rizik dok preostali, sistemski, rizik pokazuje da prinos skoro svake hartije od vrednosti zavisi od učinka tržišta i neizvesnosti vezane za opšta ekonomska kretanja. Istraživanja obavljena na različitim tržištima akcija pokazala su da se u proseku $50 \%$ rizika eliminiše formiranjem slučajno odabranog portfolija od pet do deset akcija (Whitmore, 1970). Istim istraživanjima je pokazano da se povećanjem broja akcija sa deset na više ne može značajno redukovati rizik portfolija. Takođe, istraživanja koja su sprovodili McEnally i Boardman (1979), a odnose se na tržište obveznica, sugerišu da je uticaj diversifikacije portfolija obveznica $\mathrm{u}$ visokoj korelaciji sa zaključcima koji se odnose na tržište običnih akcija.

Doprinos portfolio teoriji daju Sharpe (1964), koji je razvio model vrednovanja kapitalne aktive (Capital Asset Pricing Model, CAPM) i Ross (1976) koji je formirao model arbitražnog vrednovanja (Arbitrage Pricing Theory, APT). Ovi modeli predstavljaju osnovu za procenu vrednosti hartije od vrednosti u uslovima postojanja ravnoteže na finansijskom tržištu. Modeli su izgrađeni na određenim pretpostavkama kojima su pojednostavljeni tržišni uslovi privređivanja. Stoga je znatno smanjen broj ulaznih podataka potreban za portfolio izbor i ograničena njihova aplikativnost $\mathrm{u}$ današnjim uslovima privređivanja. Svakako najznačajniji nedostatak savremene portfolio teorije jeste to što zanemaruje činjenicu da $\mathrm{u}$ uslovima krize koeficijenti korelacije teže jedinici, te nestaju prednosti diversifikacije (Fabozzi \& Modigliani, 1996). Kao reakcija na povećanje broja i intenziteta rizika u metodološkom smislu, metoda procene vrednosti pri riziku (Value at Risk, VaR) predstavlja prirodnu progresiju portfolio teorije (Beder, 1995). VaR izražava rizik kao maksimalno mogući gubitak portfolija zbog negativnih tržišnih kretanja tokom definisanog vremena za datu verovatnoću, uz pretpostavku da se portfoliom ne upravlja tokom perioda (Hull, 2010). Suština primene ovog modela je da se uz određeni nivo statističke pouzdanosti neće izgubiti predstavljena 
vrednost pod rizikom $\mathrm{u}$ definisanom vremenskom horizontu. Ipak, treba naglasiti da primena $\mathrm{VaR} u$ praksi ima niz značajnih ograničenja koja se odnose na postojanje pretpostavke normalnosti i stacionarnosti raspodele serija prinosa (Kim \& Finger, 2000).

$\mathrm{U}$ duhu originalne Markowitz-eve metodologije, sve do sada poznate portfolio modele karakteriše diversifikacija portfolija i konstruisanje optimalnog portfolija (Back, 2010). Iako se u teorijskim modelima pretpostavlja da je diversifikacija najbolji izbor u praksi, to nije slučaj. Naime, u cilju razumevanja mogućnosti diversifikacije, kao strategije delovanja, istraživanjima je uočeno da se diversifikacijom dolazi do prosečnog rezultata (Semmler, 2011). Na taj način, diversifikacija odgovara onim investitorima na finansijskom tržištu koji ne mogu pouzdano proceniti kretanja u budućnosti, kao i onim investitorima koji imaju odbojnost prema riziku (Rubinstein, 2002).

\section{KONCEPT RIZIKA U FINANSIJSKOM POSLOVANJU}

U uslovima globalizacije, deregulacije i intenzivnog razvoja i primene informacione tehnologije dolazi do rasta povezanosti i međuzavisnosti finansijskih tokova. Povezanost i međuzavisnost su pretpostavke pozitivne i negativne sinergije (Đuričin, 2009). Teorijski argumenti $\mathrm{u}$ korist međuzavisnosti zasnivaju se na fundamentalnoj teoremi ekonomije blagostanja (konkurencija na tržištu obezbeđuje Paretov optimum) i teoriji o efikasnom finansijskom tržištu (sve informacije se na finansijskom tržištu odmah i u potpunosti, inkorporiraju u odluke učesnika na tržištu) (Eatwell, 1996). S druge strane, moralni hazard je negativna pojava koja se lako pretvara u turbulenciju koja se teško predviđa. Ekonomija moralnog hazarda stvara debalans između stvorene vrednosti $\mathrm{u}$ realnom sektoru i emitovane vrednosti u finansijskom sektoru. Navedeni debalans formira "spekulativni balon", usled čijeg pucanja prestaje da postoji ekonomija moralnog hazarda, ali pucanje "spekulativnog balona" uzrokuje krizu koja izaziva kaskadni efekat koji se širi na nivo globalne ekonomije.

U globalnom ambijentu rizik postaje neodvojiva komponenta ekonomske aktivnosti učesnika u realnom i finansijskom sektoru. Rizik se povezuje sa neizvesnošću realizacije budućih ishoda. U širem smislu, rizik predstavlja mogućnost da se dogodi neki neočekivani događaj koji može ostaviti posledice na postavljene ciljeve. Pri tome, posledice mogu biti kako pozitivne, tako i negativne. Međutim, u užem smislu, rizik predstavlja šansu da se neželjeni događaj desi. To je situacija u kojoj postoji mogućnost negativnog odstupanja stvarnog od željenog ishoda, odnosno, realizacija rizika će negativno uticati na ostvarenje definisanih ciljeva.

Verovatnoća odstupanja stvarnog od željenog ishoda je ključna odrednica u definisanju rizika. Investitori nastoje da ostvare visoke prinose na svoje investicije. Međutim, većina investitora ima odbojnost prema riziku. Rizici umanjuju marginalnu korisnost bogatstva, jer je funkcija korisnosti konkavna u odnosu na bogatstvo (Slika 1). Dodatni ili marginalni prirast bogatstva povećava korisnost za sukcesivno manje iznose, tako da investitori sa konkavnom funkcijom korisnosti poseduju smanjenu marginalnu korisnost bogatstva. Za bilo koji nivo bogatstva, dati pad bogatstva dovodi do većeg pada korisnosti nego što isti rast bogatstva dovodi do povećanja korisnosti.

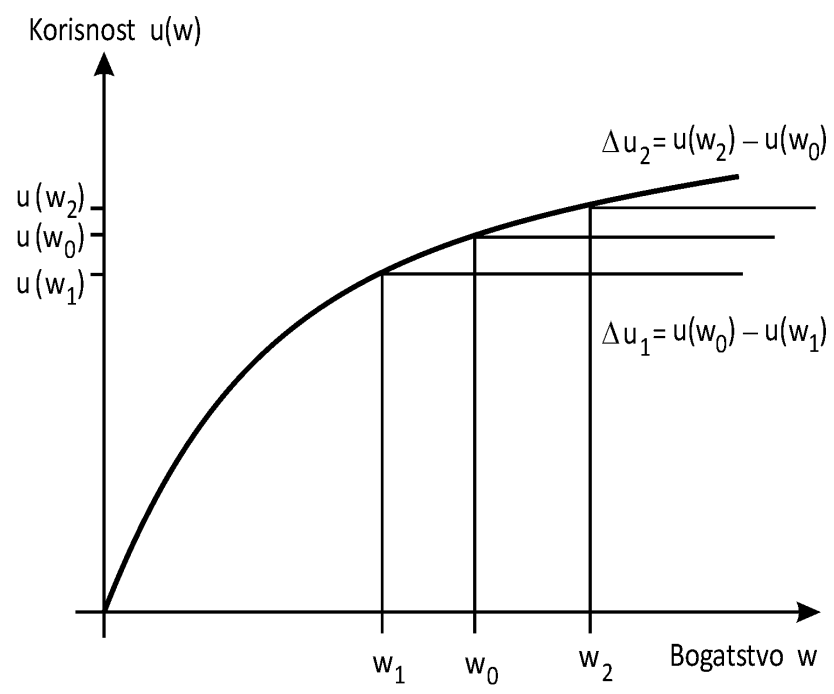

Slika 1 Konkavna funkcija korisnosti

Izvor: Barucci, 2003, 21 
Kao što se može videti, nivo korisnosti ili satisfakcije raste sve manje kako raste bogatstvo. Inicijalni nivo bogatstva $\mathrm{w}_{0}$ implicira nivo korisnosti od $\mathrm{u}\left(\mathrm{w}_{0}\right)$. Ukoliko bogatstvo padne za iznos $\Delta \mathrm{w}_{1}=\mathrm{w}_{0}-\mathrm{w}_{1}$, korisnost pada za iznos $\Delta \mathrm{u}_{1}=\mathrm{u}\left(\mathrm{w}_{0}\right)-\mathrm{u}\left(\mathrm{w}_{1}\right)$. S druge strane, ako bogatstvo poraste za isti iznos $\Delta \mathrm{w}_{2}=\mathrm{w}_{2}-\mathrm{w}_{0}$, korisnost raste za iznos $\Delta \mathrm{u}_{2}=\mathrm{u}\left(\mathrm{w}_{2}\right)-\mathrm{u}\left(\mathrm{w}_{0}\right)$. Kada je umanjena marginalna korisnost, $\Delta \mathrm{u}_{1}$ je uvek veće nego $\Delta \mathrm{u}_{2}$.

Racionalni investitori, koji imaju odbojnost prema riziku, neće odabrati rizičnu investiciju koja nudi isti očekivani prinos kao i investicija koja je oslobođena od rizika. Zapravo, oni nisu spremni da prihvate dodatni rizik koji nije kompenzovan dodatnim prinosom (premija na rizik). S druge strane, investitori koji su neutralni prema riziku imaju linearnu funkciju korisnosti koja prikazuje konstantnu marginalnu korisnost bogatstva $i$ stoga će biti indiferentni prema izboru nerizične ili rizične investicije, koje nude isti očekivani prinos. Za takve investitore važi $\Delta \mathrm{u}_{1}=\Delta \mathrm{u}_{2}$. Na kraju, investitori koji prihvataju rizik imaju konveksnu funkciju korisnosti koja prikazuje povećanje marginalne korisnosti bogatstva. Stoga će oni preferirati rizične investicije, jer je $u$ ovom slučaju $\Delta \mathrm{u}_{2}>\Delta \mathrm{u}_{1}$.

Uzimajući u obzir navedeno, potrebno je naglasiti da se $\mathrm{u}$ poslednje tri decenije rizik potcenjivao $\mathrm{i} / \mathrm{ili}$ prenosio na druge. To je uticalo na izmenu strategije prema riziku u smislu da su strategije investitora visoko odbojnih na rizik evoluirale u strategije koje karakteriše visoka sklonost riziku. Očigledno je da se u uslovima globalne finansijske krize i recesije odnos prema riziku mora promeniti. Izbegavanje rizika u uslovima niskog nivoa ekonomske aktivnosti nije poželjno. Ono što je potrebno je upravljanje rizikom, ali na inteligentan način koji doprinosi stvaranju vrednosti (Đuričin, 2009).

\section{PROCES UPRAVLJANJA RIZICIMA U FINANSIJSKIM POSLOVIMA}

Upravljanje rizicima čini sastavni deo upravljačke aktivnosti u svim sektorima. Reč je o konceptu koji podrazumeva skup koordinisanih aktivnosti upravljanja i kontrolisanja organizacije u pogledu rizika (PD ISO/IEC Guide 73:2002). U izmenjenim uslovima poslovanja očigledno je da je potreban nov model upravljanja rizicima koji se bazira na identifikovanju potencijalnih rizika, njihovoj proceni i merenju, uočavanju posledica i, na osnovu toga, preduzimanju adekvatnih strategija, kao što su izbegavanje, transfer, prevencija i zadržavanje ili čuvanje rizika (Slika 2).

Ovaj, naizgled jednostavan, niz prikazanih aktivnosti ukazuje na to da je $\mathrm{u}$ pitanju kontinuelni proces upravljanja rizicima. Međutim, proces upravljanja rizicima ne sme se posmatrati samo kao proces odbrane od rizika, jer finansijske institucije biraju vrstu i nivo rizika koji je za njih prihvatljiv za preuzimanje. Većina poslovnih odluka podrazumeva žrtvovanje tekućeg

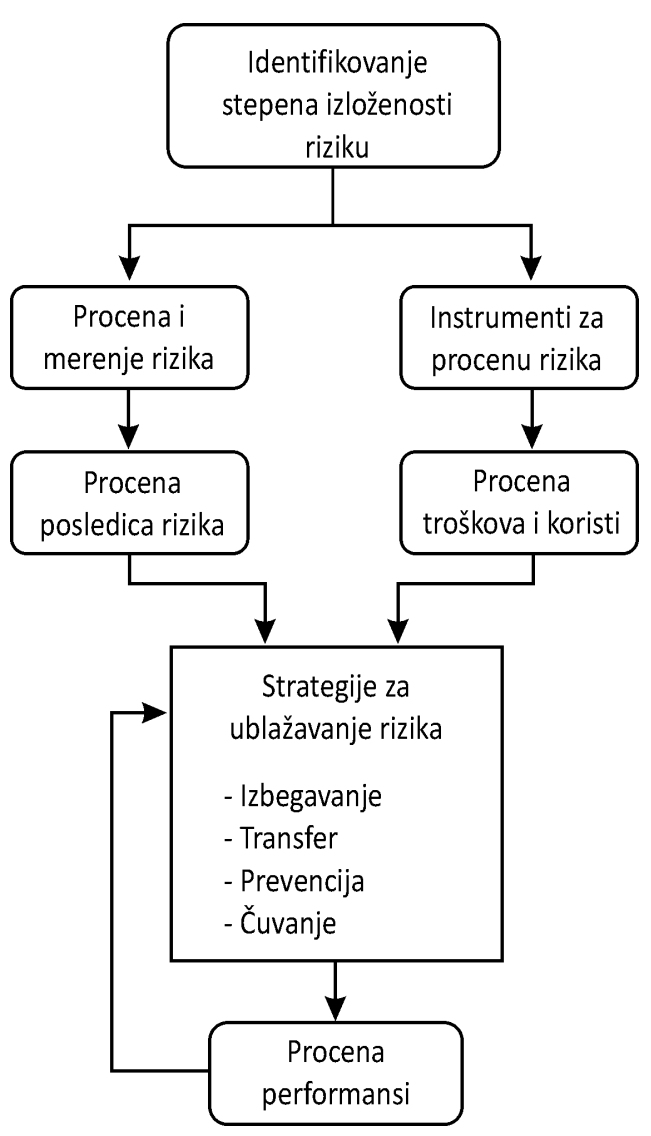

Slika 2 Proces upravljanja rizicima

Izvor: Crouhy \& Robert, 2006, 2 
prinosa zarad budućih neizvesnih prinosa. Upravljanje rizicima i preuzimanje rizika nisu suprotstavljene aktivnosti, već predstavljaju dve strane istog procesa. Upravo koncept proširenog upravljanja rizicima se ne bazira samo na izbegavanju rizika, već i na korišćenju rizika (Segal, 2006). U uslovima niskog nivoa ekonomske aktivnosti, nužno je upravljati rizicima na način koji će doprineti izboru strategije koja donosi najveću vrednost za prihvatljivi nivo rizika.

Ponekad je i naizgled jednostavan postupak identifikovanja rizika kompleksan, jer je teško povući jasnu granicu gde jedan rizik prestaje, a drugi počinje. Takođe je vrlo složena metodologija za kvantifikovanje rizika. Mere za kvantifikovanje rizika su brojne i zavise od vrste rizika koji se želi proceniti. Za kvantifikovanje rizika najčešće se koristi: varijansa i standardna devijacija, procena neto sadašnje vrednosti, interna stopa prinosa, procena cene uloženog kapitala, arbitražno vrednovanje, kao i vrednost pri riziku (Hull, 2010).

Nakon kvantifikovanja rizika i uočavanja posledica dolazi se do složene faze koja se tiče izbora pristupa i instrumenata za upravljanje rizicima. Rizike koji nisu kompenzovani željenim prinosom finansijske institucije izbegavaju. To mogu da čine prodajom finansijske aktive koja je opterećena tom vrstom rizika (na primer, sekjuritizacijom plasmana i/ili ulaskom $u$ hedžing transakcije). Prednost ove metode je $u$ tome što opasnost od nastanka ekonomski štetnog događaja nestaje ili je bitno smanjena. Međutim, ona ima i određene nedostatke. Kao jedan od nedostataka navodi se nemogućnost izbegavanja svih rizika kojima je kompanija izložena. Drugi nedostatak je to što su rizične aktivnosti, po pravilu, profitabilne, te su oportunitetni troškovi visoki (Barucci, 2003).

Transfer rizika podrazumeva prenos rizika, kome su izložene finansijske institucije, na učesnike na tržištu koji su spremni da rizik preuzmu. Najčešće se realizuje kupovinom osiguranja, prodajom i kupovinom potraživanja na promptnom tržištu i ulaskom u transakcije na terminskom tržištu. Pojedine rizike finansijske institucije svesno preuzimaju. To su oni rizici koji proističu iz neophodnih svakodnevnih aktivnosti, a koji su podložni moralnom hazardu ili kod kojih se ne može izvršiti neutralisanje rizika.
Kada se donese odluka da se preuzme određeni rizik, neophodno je definisati postupke za dalje upravljanje rizikom. Jedan od dokazano efikasnih načina za upravljanje rizikom je diversifikacija plasmana kojim se umanjuje frekvencija kako dobrih, tako i loših ishoda, što umanjuje verovatnoću nastanka gubitka.

Ukoliko nije moguće izvršiti diversifikaciju plasmana, ponekad je jeftinije formirati rizični pul nego platiti osiguranje (Schroeck, 2002). Ukoliko nije moguće primeniti nijedan od navedenih instrumenata upravljanja rizicima, pribegava se držanju potrebnog kapitala koji zavisi od projekcije neočekivanog gubitka, a služi za pokriće očekivanog gubitka (Hull, 2010).

Za rizike slabog intenziteta sa velikom verovatnoćom javljanja preporučuje se prevencija i redukcija rizika, dok se kod rizika sa jakim intenzitetom i velikom verovatnoćom javljanja preporučuje metoda izbegavanja rizika. S druge strane, ukoliko je mala verovatnoća javljanja i veliki rizik, preporučuje se metoda koja podrazumeva upotrebu osiguranja, dok se kod rizika slabog intenziteta koji imaju malu verovatnoću javljanja preporučuje zadržavanje rizika (Rejda, 2008).

\section{USLOVLJENOST PRINOSA I RIZIKA}

Kao što je poznato, prisustvo rizika ne sprečava investitore da svoja raspoloživa sredstva ulažu $u$ različite oblike finansijske aktive. Međutim, prisustvo rizika utiče na očekivanja investitora $u$ pogledu budućeg prinosa. Za razliku od bezrizične aktive gde se prinos sa sigurnošću zna, kod rizične aktive prinos koji investitor treba da ostvari je krajnje neizvestan. Otuda, prilikom ulaganja u rizičnu aktivu, potencijalni investitor ima određena očekivanja o visini željenog prinosa koji bi njegovo ulaganje trebalo da donese. Taj očekivani nivo prinosa predstavlja minimum ispod kojeg investitor nije spreman da ulaže svoja finansijska sredstva. Mogućnost ostvarenja niže stope prinosa od očekivane čini konkretno ulaganje rizičnim. Standardno ponašanje investitora podrazumeva njegovo očekivanje da će realizovati maksimalni prinos za prihvatliivi nivo rizika, odnosno, minimalni rizik za dati nivo prinosa. 
Evidentno je da se retko mogu pronaći investitori koji koncentrišu svoje bogatstvo u jednu vrstu hartija od vrednosti. Zbog visokih transakcionih troškova povećava se rizik osvarenja neočekivanog gubitka. Umesto toga, oni teže da investiranju u skup hartija od vrednosti različitih vrsta i karakteristika, odnosno, u portfolio hartija od vrednosti. Na taj način se može smanjiti visina rizika očekivanog prinosa, koja zavisi kako od apsolutnog rizika svakog ulaganja u portfolio, tako i od veze koja postoji između pojedinih plasmana u okviru portfolija. U slučaju da portfolio čine plasmani među kojima postoji niska korelacija opsega varijacija budućih očekivanih prinosa može se očekivati da rizik portfolija bude manji od zbira rizika pojedinačnih ulaganja.

Ukoliko je veća varijansa ili standardna devijacija, veća je i disperzija budućeg prinosa oko očekivanog prinosa, odnosno, veća je investitorova nesigurnost. Dok je standardna devijacija za pojedinačne hartije od vrednosti veća nego za portfolio hartija od vrednosti, prosečan prinos kod pojedinačnih hartija od vrednosti je niži nego prinos portfolija. Prinos portfolija je procenjeni prosek prinosa pojedinačnih hartija od vrednosti koje čine portfolio i on se može predstaviti na sledeći način (Blake, 2000):

$r_{p}=\sum_{i=1}^{N} \theta_{i} r_{i}$

gde su:

$r_{p}$ - prinos portfolija,

$N$ - broj hartija od vrednosti u portfoliju,

$r_{i}$ - prinos i-te hartije od vrednosti u portfoliju,

$\theta_{i}$ - učešće i-te hartije od vrednosti u portfoliju, gde je

$\sum_{i=1}^{N} \theta_{i}=1$

S obzirom na to da je prinos portfolija u nekom budućem vremenu $\left(t_{1}\right)$ krajnje neizvestan, $u$ sadašnjem vremenu $\left(t_{0}\right)$ očekivani prinos portfolija je ponderisan prosek očekivanih prinosa pojedinih elemenata portfolija gde kao ponderi služe verovatnoće realizacije mogućih ishoda, odnosno, očekivani prinos portfolija je izražen prosekom očekivanih prinosa na pojedinačne hartije od vrednosti u svim mogućim budućim scenarijima, ponderisan verovatnoćom da se taj scenario dogodi:

$\bar{r}_{p}=\sum_{i=1}^{N} \theta_{i} \bar{r}_{i}$

gde su:

$\bar{r}_{p}=E\left(r_{p}\right)$ - očekivani prinos portfolija,

$\overline{r_{i}}=E\left(r_{i}\right) \quad-$ očekivani prinos i-te hartije od vrednosti u portfoliju.

Korišćenjem jednačina (1) i (2), varijansa portfolija (ili rizik portfolija) je predstavljena na sledeći način (Blake, 2000):

$$
\begin{aligned}
& \sigma_{p}^{2}=E\left(r_{p}-\bar{r}_{p}\right)^{2}=E\left[\sum_{i=1}^{N} \theta_{i}\left(r_{i}-\bar{r}_{i}\right)\right]^{2}= \\
& =\sum_{i=1}^{N} \sum_{j=1}^{N} \theta_{1} \theta_{j} \sigma_{i j}=\sum_{i=1}^{N} \sum_{j=1}^{N} \theta_{i} \theta_{j} \sigma_{i} \sigma_{j} \rho_{i j}
\end{aligned}
$$

gde su:

$\sigma_{p}^{2} \quad$ - varijansa prinosa portfolija,

$\sigma_{i i}=\sigma_{i}^{2}=E\left(r_{i}-\bar{r}_{i}\right)^{2} \quad$ - varijansa prinosa i-te hartije od vrednosti,

$\sigma_{i}=\sqrt{E\left(r_{i}-\overline{r_{i}}\right)^{2}} \begin{gathered}\text { standardna devijacija prinosa i-te } \\ \text { hartije od vrednosti, }\end{gathered}$ $\sigma_{i j}=E\left(r_{i}-\bar{r}_{i}\right)\left(r_{j}-\bar{r}_{j}\right)$ - kovarijansa prinosa i-te i j-te hartije od vrednosti,

$\rho_{i j}=\sigma_{i j} / \sigma_{i} \sigma_{j}$ - koeficijent korelacije prinosa i-te i j-te hartije od vrednosti.

Da bi se izmerio rizik portfolija, neophodno je poznavati ne samo varijansu hartija od vrednosti koje čine portfolio, nego i uzajamni odnos (korelaciju) očekivanih prinosa, odnosno, stepen i smer slaganja kretanja očekivanih prinosa svakog para hartija od vrednosti iz portfolija. Ukoliko su prinosi na dve hartije od vrednosti perfektno (pozitivno) korelisani, onda je koeficijent korelacije +1 (Slika 3a). Ukoliko su prinosi na hartije od vrednosti perfektno (negativno) korelisani, koeficijent korelacije je -1 (Slika 3b). Kada su prinosi nekorelisani, koeficijent korelacije ima nultu vrednost (Slika 3c). Racionalan investitor koji ima odbojnost prema riziku izabraće savršeno negativno 


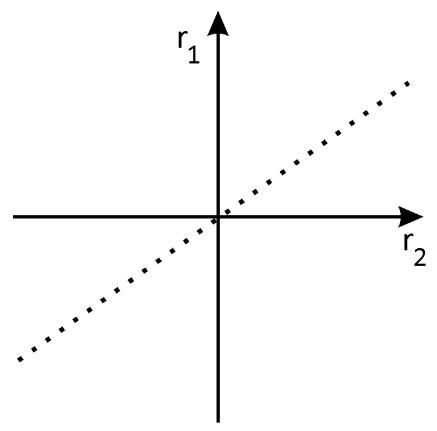

(a)

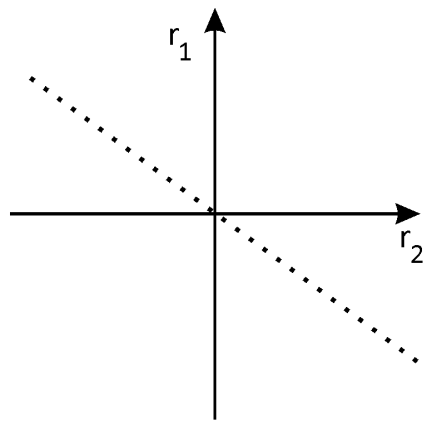

(b)

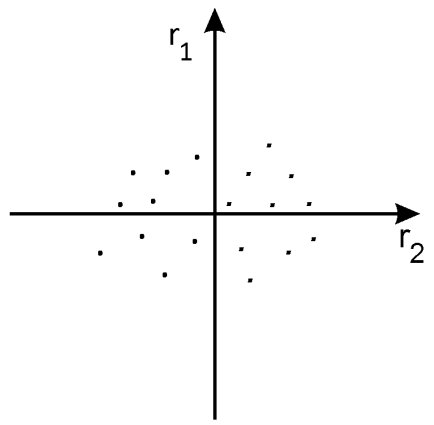

(c)

Slika 3 Prinosi na dve hartije od vrednosti: a) perfektna (pozitivna) korelacija, b) perfektna (negativna) korelacija, c) odsustvo linearne veze

Izvor: Sharpe, Alexander \& Bailey, 1995, 180

korelisane prinose, odnosno, nerizičan portfolio (Sharpe, Alexander \& Bailey, 1995). Ukoliko između svakog pojedinačnog para ulaganja postoji slaba veza, onda se može očekivati da rizik portfolija bude manji od zbira rizika pojedinačnih ulaganja u portfolio. Generalno, što je slabija korelacija među hartijama od vrednosti, veći je uticaj diversifikacije na smanjenje varijabiliteta.

Ukupni rizik portfolija, odnosno, standardna devijacija portfolija opada kako se povećava broj hartija od vrednosti u portfoliju. Tako je prag na kome se ukupni rizik porfolija svodi na tržišni ili sistemski rizik veoma nizak. Otuda rizik potpuno diversifikovanog portfolija zavisi od tržišnog rizika hartija od vrednosti uključenih $\mathrm{u}$ portfolio. Mera sistemskog rizika je $\beta$ koeficijent. On meri osetljivost prinosa pojedinačne hartije od vrednosti na promenu prinosa tržišnog portfolija. Ukoliko tržišni indeks raste, vrednost konkretne hartije od vrednosti, bez obzira na stepen diversifikacije, imaće rastući trend. Ako je tržišni indeks u padu, i vrednost konkretne hartije od vrednosti biće u padu. Koeficijent $\beta$ je linearna mera tog odnosa (Slika 4).

Ukoliko postoji direktna proporcionalnost prinosa pojedinih vrednosnih papira sa prinosom tržišnog portfolija, vrednost koeficijenta $\beta$ iznosi jedan $(\beta=1)$. Stopa prinosa hartije od vrednosti dugoročno će fluktuirati $\mathrm{u}$ istom smeru i stepenu kao i stopa prinosa tržišnog portfolija. U slučaju kada je vrednost koeficijenta $\beta$ veća od jedan $(\beta>1)$, promena stope prinosa vrednosnog papira je veća od promene stope prinosa tržišnog portfolija (agresivno ulaganje). U

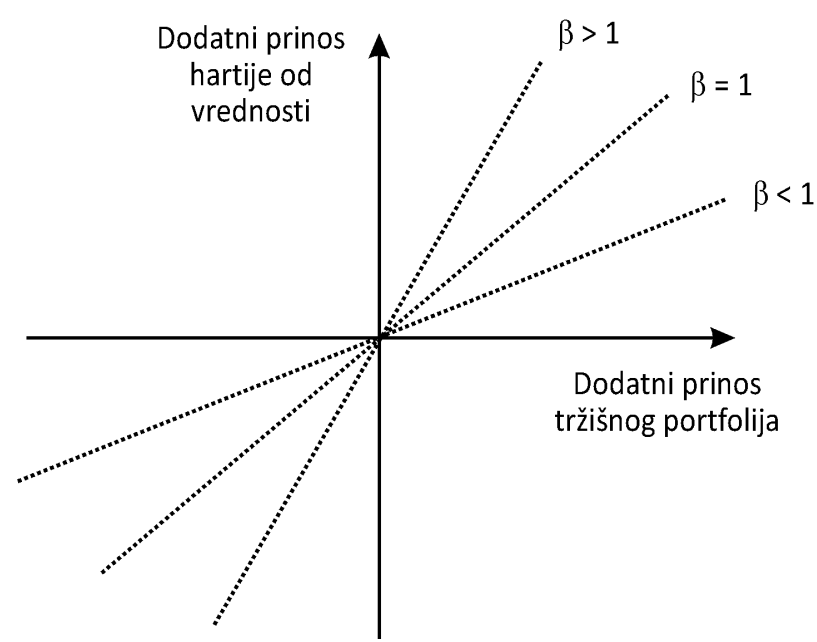

Slika 4 Karakteristična linija sa različitim $\beta$ koeficijentom

Izvor: Van Horne \& Wachowicz, 1998, 101 
slučaju kada je vrednost koeficijenta $\beta$ manja od jedan $(\beta<1)$, ulaganje obećava niži dodatni prinos od dodatnog prinosa tržišnog portfolija (defanzivna ulaganja).

Koeficijent $\beta$ pojedinačnih ulaganja $u$ hartije od vrednosti $u$ portfoliju određuje visinu rizika tog portfolija. Koeficijent $\beta$ portfolija se utvrđuje kao ponderisana sredina koeficijenta $\beta$ pojedinačnih članova portfolija. Kao ponder obično se koristi procentualno učešće ulaganja u portfoliju. Matematički iskaz navedenog glasi (Fabozzi \& Modigliani, 1996):

$\beta_{p}=\sum_{i=1}^{n} W_{i} \beta_{i}$

gde su:

$\beta_{p}$ - koeficijent $\beta$ portfolija,

$\beta_{i}-$ koeficijent $\beta$ i-tog člana portfolija,

$W_{i}$ - deo ukupnog ulaganja u portfolio uložen u i-ti član portfolija.

Čitajući navedenu formulu na osnovu (4), zaključuje se da koeficijent $\beta$ portfolija predstavlja ponderisan prosek pojedinačnih koeficijenata $\beta$ hartija od vrednosti iz portfolija, gde su ponderi udeli ukupne tržišne vrednosti portfolija predstavljeni svakom hartijom. Brojne organizacije redovno publikuju izračunate koeficijente $\beta$ za akcije koje su predmet aktivne trgovine. Iako ovaj koncept nije bez nedostataka, on predstavlja prihvatljivu i često korišćenu osnovu za kvantifikovanje sistemskog rizika pojedinačnih hartija od vrednosti ili portfolija kao celine.

Sistemski rizik $\left(S_{r}\right)$ hartija od vrednosti predstavlja proizvod koeficijenta $b$ i standardne devijacije tržišnog prinosa $\left(\operatorname{std}\left(\mathrm{R}_{\mathrm{M}}\right)\right)$ :

$\mathrm{S}_{\mathrm{r}}=\beta \operatorname{std}\left(\mathrm{R}_{\mathrm{M}}\right)$

Analogno prethodnom, ukoliko je dat sistemski rizik pojedinačne hartije od vrednosti, može se izračunati sistemski rizik portfolija $\left(\mathrm{S}_{\mathrm{rp}}\right)$ :

$S_{\mathrm{rp}}=\beta_{\mathrm{p}} \operatorname{std}\left(\mathrm{R}_{\mathrm{M}}\right)$

Može se zaključiti da je osnovni smisao kvantifikovanja kako sistemskog, tako i nesistemskog, rizika izračunavanje ukupnog rizika portfolija. Veliki deo ukupnog rizika može se eliminisati diversifikacijom. Sve dok se veći deo ukupnog rizika može eliminisati diversifikacijom, nema ekonomskih zahteva da ostvareni prinos bude vezan za ukupni rizik. Umesto toga, može se očekivati da ostvareni prinos bude povezan sa delom rizika koji se ne može eliminisati (sistemski rizik).

\section{IZBOR PORTFOLIJA SA NAJBOLJIM KARAKTERISTIKAMA}

Kombinovanjem različitih hartija od vrednosti koje su dostupne na tržištu moguće je dobiti veliki broj portfolija. Međutim, sve moguće kombinacije imaju svoju granicu rasprostiranja. Pošto na finansijskom tržištu investitor ima mogućnost kombinovanja velikog broja hartija od vrednosti, granica rasprostiranja ima oblik prikazan na Slici 5. Skup mogućih portfolija prikazan je kao osenčena površina AHBQ. Ovaj skup portfolija zadovoljava pretpostavku da investitori imaju savršena i homogena očekivanja u pogledu budećeg prinosa hartija od vrednosti.

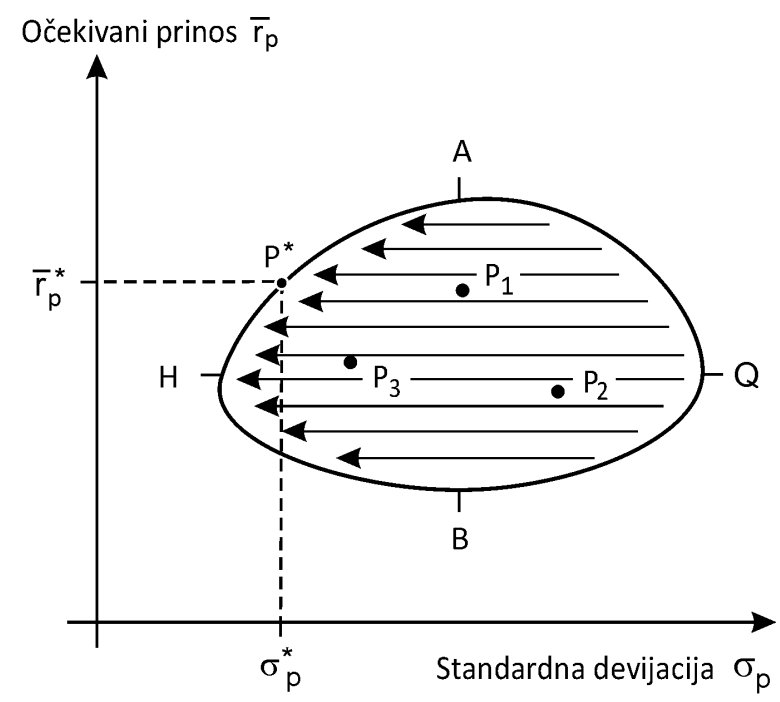

Slika 5 Izvodljiv i efikasan skup

Izvor: Blake, 2000, 475 
Potrebno je uočiti da nije svaki portfolio u skupu portfolio mogućnosti interesantan za razmatranje. Na primer, to je slučaj sa portfolijima nad kojima jasno dominiraju drugi portfoliji. Jedan portfolio će dominirati nad drugim ako ima manju standardnu devijaciju za isti očekivani prinos, ili veći očekivani prinos za istu standardnu devijaciju. Portfoliji nad kojima dominiraju drugi portfoliji poznati su $\mathrm{u}$ finansijskoj teoriji kao neefikasni portfoliji. Svi portfoliji $\mathrm{u}$ okviru skupa portfolio mogućnosti (kao što su $\mathrm{P}_{1}$, $\mathrm{P}_{2}, \mathrm{P}_{3}$ ) su oni nad kojima dominiraju portfoliji na levoj strani portfolio granice. Ova, leva, granica poznata je kao skup portfolio mogućnosti sa minimalnom standardnom devijacijom. Svi portfoliji koji su smešteni na granici rasprostiranja HA zadovoljavaju uslov da za dati nivo očekivanog prinosa imaju najmanju standardnu devijaciju. To su efikasni portfoliji, a njihov skup čini skup efikasnih portfolija koji predstavlja deo skupa portfolio mogućnosti sa minimalnom standardnom devijacijom koji ne sadrži neefikasne portfolije.

Postavlja se pitanje šta se dešava ako u efikasnom skupu, osim rizičnih hartija od vrednosti, postoje nerizične hartije od vrednosti, pri čemu te nerizične hartije od vrednosti mogu biti pozajmljene po jedinstvenoj nerizičnoj stopi prinosa. Inicijalno, razmatra se portfolio koji se sastoji od samo jedne rizične hartije od vrednosti $\left(\mathrm{x}_{1}\right)$ i jedne nerizične hartije od vrednosti $\left(\mathrm{x}_{\mathrm{f}}\right)$. Očekivani prinos portfolija je (Blake, 2000):

$\bar{r}_{p}=\theta_{1} \bar{r}_{i}+\theta_{2} \bar{r}_{f}$

gde su:

$\bar{r}_{f}$ - nerizična stopa prinosa,

$\theta_{1}$ - proporcija bogatstva sadržanog u rizičnoj hartiji od vrednosti, $\theta_{2}=1-\theta_{1}$

Standardna devijacija portfolija je:

$\sigma_{\mathrm{p}}=\theta_{1} \sigma_{1}$

što proizilazi iz definicije koja glasi da stopa prinosa oslobođena rizika ima nultu varijansu $\left(\sigma_{\mathrm{f}}^{2}=0\right)$ i nije $\mathrm{u}$ korelaciji sa prinosom rizične aktive $\left(\sigma_{1 \mathrm{f}}=0\right)$. Jednačine (7) i (8) daju linearni skup portfolio mogućnosti. U tački C investitor formira portfolio ulažući u nerizičnu aktivu (prinos na portfolio je $r_{f}$ i rizik portfolija je nula). U tački M (Slika 6) investitor formira portfolio plasirajući sredstva $u$ rizična ulaganja, sa očekivanim prinosom $\bar{r}_{i} i$ očekivanim rizikom $\sigma_{i}$. U bilo kojoj tački koja se nalazi između $\mathrm{C}$ i $\mathrm{M}$ deo portfolija čine rizična ulaganja (to jest, $0<\theta_{1}<1$ ), a deo nerizična ulaganja.

Pronalaženjem skupa portfolio mogućnosti za nerizična ulaganja i jedno rizično ulaganje, može se pronaći skup portfolio mogućnosti i efikasan skup kada se nerizično ulaganje kombinuje sa rizičnim ulaganjem (Slika 6). $\mathrm{Na}$ primer, kada se nerizično ulaganje kombinuje sa rizičnim portfoliom K, stvara se skup portfolio mogućnosti CKP. Slično, kada je nerizično ulaganje kombinovano sa rizičnim portfoliom A, stvara se skup portfolio mogućnosti CAJ.

Ovaj skup portfolio mogućnosti dominira nad CKP, jer svaki portfolio na liniji CAJ ima viši očekivani prinos nego svaki portfolio na liniji CKP sa istom standardnom devijacijom. Skup portfolio mogućnosti nad kojim ne dominira nijedan drugi je onaj koji proizilazi iz kombinovanja nerizične aktive sa rizičnim portfoliom. Na Slici 6 portfolio $\mathrm{M}$ je onaj koji

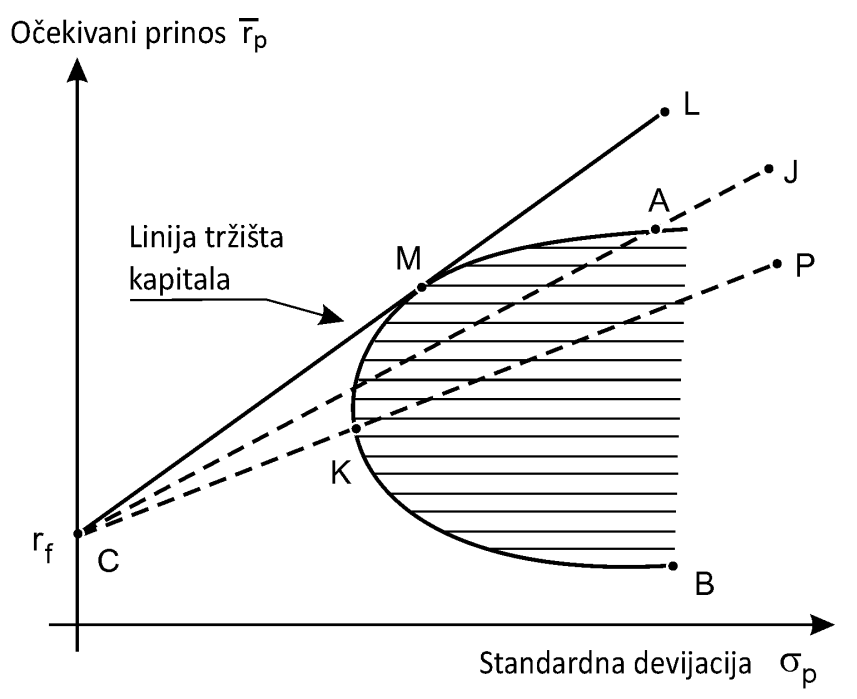

Slika 6 Skup portfolija sa nerizičnom aktivom

Izvor: Blake, 2000, 477 
leži u tački tangente između segmenta linije CML i konveksnog seta rizičnih portfolija AMKB. Kada postoji nerizična aktiva koja može biti pozajmljena ili data po istoj nerizičnoj stopi, efikasan skup uključuje sve portfolije koji čine kombinaciju nerizičnog ulaganja i rizičnog portfolija M. To implicira da je efikasan skup na segmentu linije CML. Koeficijent nagiba granice efikasnih portfolija CML predstavlja tržišnu cenu rizika koja pokazuje koliko dodatnog prinosa, iznad nivoa nerizičnog prinosa, investitori zahtevaju da se izlože jedinici dodatnog rizika:

Tržišna cena rizika $=\frac{\overline{r_{m}}-r_{f}}{\sigma_{m}}$

gde su:

$\bar{r}_{m}$-očekivani prinos portfolija $\mathrm{m}$,

$\sigma_{m}-$ standardna devijacija portfolija $\mathrm{m}$.

Jednačina meri potreban rast očekivanog prinosa koji investitoru nadoknadi dodatnu jedinicu rizika. To se može jasnije videti kada se razmatra jednačina linije tržišta kapitala (Capital Market Line - CML): $\bar{r}_{p}=r_{f}\left(\frac{\bar{r}_{m}-r_{f}}{\sigma_{m}}\right) \sigma_{p}$

gde su:

$\overline{\mathrm{r}}_{p}$ - očekivani prinos portfolija duž $\mathrm{CML}$,

$\sigma_{p}$ - standardna devijacija portfolija duž CML.

Sve dok postoje homogena očekivanja u pogledu rizika i prinosa, svaki investitor će se složiti s tim da je tržišna cena rizika istovremeno marginalna stopa transformacije rizika i prinosa i da će svi efikasni portfoliji biti procenjeni u ravnoteži shodno prethodnoj jednačini. Drugim rečima, stopa prinosa potrebna da bi efikasan portfolio bio $u$ ravnoteži biće data sa $\bar{r}_{p}$ ako je njegov nivo rizika dat sa $\sigma_{\mathrm{p}}$.

Optimalni portfolio svakog investitora biće formiran kombinacijom tržišnog portfolija i nerizične hartije od vrednosti. Tačna kombinacija tržišnog portfolija i nerizične hartije od vrednosti zavisi od stepena odbojnosti prema riziku. Naime, optimalni portfolio je određen tačkom u kojoj je kriva indiferencije tangenta na CML (Slika 7). U ovoj tački nagib krive indiferencije (koji meri marginalnu stopu supstitucije rizika i

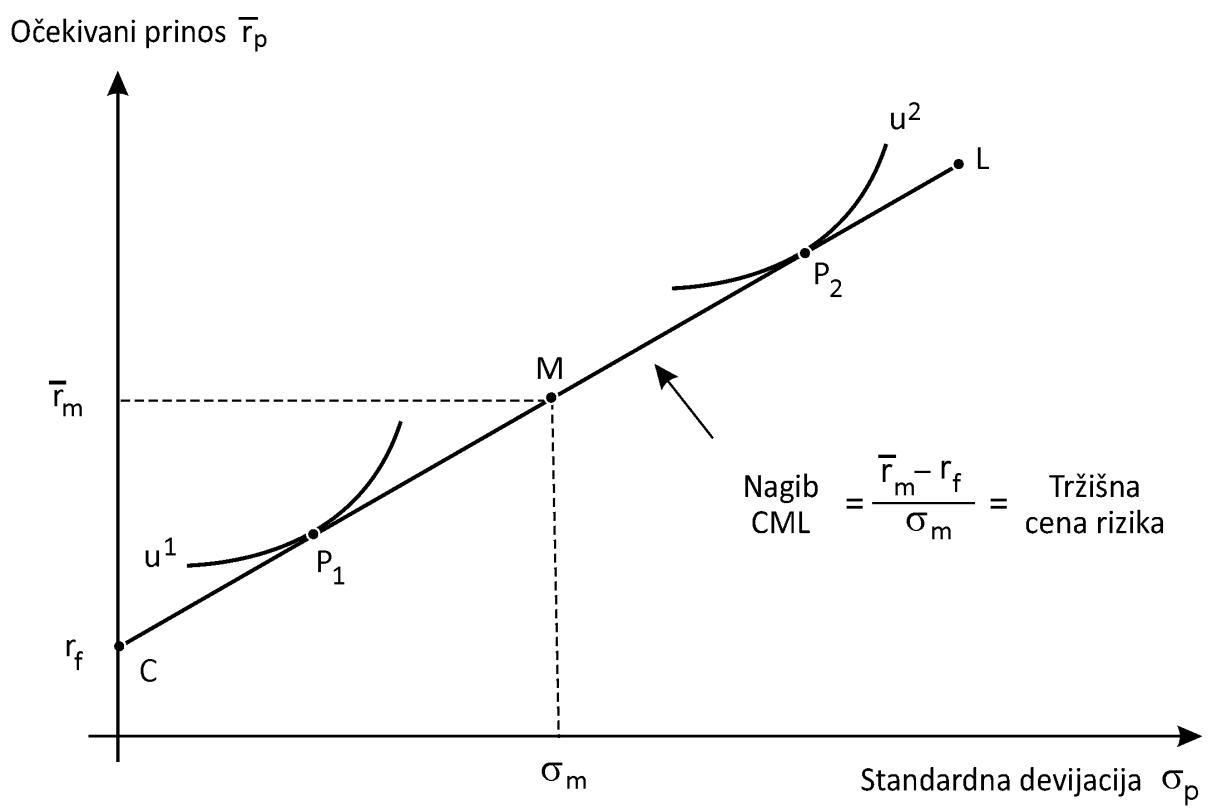

Slika 7 Optimalni portfolio i tržišna cena rizika 
prinosa) jednak je nagibu CML (koji meri marginalnu stopu transformacije rizika i prinosa:

$M R S_{1}=M R S_{2}=M R T=\frac{\overline{r_{m}}-r_{f}}{\sigma_{m}}$

gde su:

$\mathrm{MRS}_{1}$ - marginalna stopa supstitucije prinosa i rizika,

$\mathrm{MRT}_{1}$ - marginalna stopa transformacije rizika i prinosa (tržišna cena rizika).

Jednačina je standardni uslov optimalnosti u ekonomiji i može ce koristiti za izračunavanje proporcije tržišnog portfolija i nerizične hartije od vrednosti u optimalnom portfoliju. Zbog homogenosti očekivanja u konstrukciji portfolija investitori neće praviti svoje specifične kombinacije raspoloživih hartija od vrednosti. Svaki investitor će, u skladu sa sopstvenim sredstvima, konstruisati portfolio koji je isti kao optimalni portfolio.

Imajući u vidu prethodno, jasno se može izvesti zaključak, odnosno, potvrditi polazna hipoteza da, ukoliko je dat skup hartija od vrednosti u okviru koga se može napraviti izbor, portfolio teorija pruža mogućnost investitoru da odluči koja kombinacija hartija od vrednosti daje najbolji prinos za dati rizik.

\section{KRITIKA SAVREMENE PORTFOLIO TEORIJE}

Osnovna ideja na kojoj se temelji savremena portfolio teorija jeste da se izbor hartija od vrednosti za portfolio ne vrši na bazi željenih performansi hartija od vrednosti. Savremena portfolio teorija je pokazala da portfolio koji ima maksimalni očekivani prinos ne mora da bude najpovoljnija alternativa kada se $u$ analizu uključi i rizik. Ukoliko investitori nastoje da smanje rizik portfolija, nije dovoljno da investiraju $\mathrm{u}$ različite hartije od vrednosti, već je potrebno da investiraju u hartije od vrednosti koje imaju visoku kovarijansu. Na taj način je omogućeno da investitori formiraju skup efikasnih portfolija koji dominiraju nad skupom svih mogućih kombinacija raspoloživih hartija od vrednosti. Svaki portfolio koji se nalazi na granici efikasnosti znači efikasnu razmenu između prinosa i rizika. Drugim rečima, ukupan rizik kojim je opterećen efikasan portfolio biće kompenzovan po tržišno priznatoj ceni jedinice rizika.

Portfolio teorija je pokazala da, umesto slučajnog izbora i slučajnog ishoda, postoje i optimalni izbor i ishod. To je optimalni portfolio koji se nalazi u tački tangentnosti krive indiferencije na granicu efikasnosti. Investitor je indiferentan pri izboru bilo koje kombinacije rizika i očekivanog prinosa na istoj krivoj indiferencije. Portfolio na granici efikasnosti kojem krivaindiferencije nije tangenta ne predstavlja optimalni portfolio, jer ne dovodi do maksimuma funkciju korisnosti investitora. Stoga, portfolio koji je optimalan za jednog investitora ne mora da bude optimalan za drugog investitora.

Postupak izračunavanja statističkih mera disperzije prinosa $\mathrm{u}$ modelu je precizan, ali istovremeno i kompleksan kako se povećava broj uključenih hartija $\mathrm{u}$ portfolio. Takođe, model pretpostavlja stoprocentnu tačnost ulaznih parametara, što u praksi nije slučaj. Ovaj problem Michaud (1989) definiše kao problem znatno veće sofisticiranosti optimizacije algoritma $u$ odnosu na kvalitet ulaznih parametara, odnosno, predviđanja. Problem procene ulaznih parametara dobija na značaju kada se ima u vidu da se procena ulaznih parametara - očekivanog prinosa i rizika - vrši na bazi koncepta prosečne vrednosti istorijskih podataka. Ovaj koncept odbacuje multivarijabilni karakter problema, te je procena očekivanog prinosa, varijanse i kovarijanse uvek praćena izvesnom greškom. S tim u vezi, Konno i Yamazaki (1991) predložili su korišćenje apsolutne devijacije slučajnih varijabli, čime se umesto kvadratnog vrši linearno programiranje. Prema njima, apsolutna devijacija slučajne varijable je očekivana apsolutna vrednost razlike vrednosti slučajne varijable i njene srednje vrednosti i predstavlja linearnu meru rizika konzistentnu sa stohastički dominantnim redom.

Chopra i Ziemba (1993) ističu da efekat maksimiziranja greške ulaznih parametara zavisi i od sklonosti investitora riziku. U slučaju veće sklonosti riziku, greške u srednjoj vrednosti su značajnije od grešaka $\mathrm{u}$ varijansi i kovarijansi dok, u slučaju odbojnosti prema riziku, uticaj greške $u$ proceni očekivanog prinosa je približan uticaju greške u proceni varijanse i kovarijanse. Razlog tome je činjenica da je investitoru koji ima odbojnost prema riziku važnije da minimizira rizik portfolija nego da poveća očekivani prinos, pa 
je time i greška u proceni očekivanog prinosa manje značajna od greške $u$ proceni varijanse portfolija. Nezavisno od stepena odbojnosti prema riziku, smatra se da su najznačajnije greške srednje vrednosti, zatim greške $u$ varijansi, dok greške u kovarijansi imaju najmanji uticaj na optimalnost portfolija (Tumminelo et al, 2007).

Model izbora optimalnog portfolija zanemaruje i faktor likvidnosti. Uvažavanje ograničenja likvidnosti $\mathrm{u}$ procesu određivanja skupa efikasnih portfolija, $\mathrm{u}$ odnosu na klasičnu granicu efikasnosti, dovodi do manjeg povećanja prinosa i/ili smanjenja rizika.

Brojna istraživanja (Back, 2010; Semmler, 2011; Chapados, 2011; Belke \& Schneider, 2011) pokazuju da raspodele serija prinosa hartija od vrednosti odstupaju od raspodele predviđene pretpostavkama modela. Prisustvo asimetrije i odsustvo spljoštenosti u odnosu na normalnu raspodelu upućuju na zaključak da poznavanje očekivane stope prinosa i varijanse nije dovoljno da bi se izvršila optimizacija portfolija. Doprinos hartije od vrednosti varijansi portfolija uglavnom je određena kovarijansom posmatrane hartije od vrednosti i svih ostalih hartija od vrednosti u portfoliju (Rubinstein, 2002).

Mandelbrot (1963) je ukazivao na to da istorijski podaci o cenama i prinosima nisu trajni, pa statističke mere srednje vrednosti uzimaju različite vrednosti u različitim periodima. Često se dešavaju velike, trenutne promene u cenama hartija od vrednosti, te ih je lakše opisati stohastičkim modelima. Sukcesivne promene cena hartija od vrednosti ne izgledaju nezavisne, već se reflektuju kroz prepoznatljive šablone, što predstavlja osnov tehničke analize. Šablon se razlikuje od normalne distribucije, jer ima šiljat vrh, obla „ramena” i zadebljane krajeve.

\section{ZAKLJUČAK}

Globalna finansijska kriza i recesija ukazale su na opasnosti od primene inovativnih finansijskih rešenja, visokog finansijskog leveridža, propusta u upravljanju rizicima u finansijskom sektoru i rastuće povezanosti subjekata u uslovima povećane izloženosti sistemskom riziku. Očigledno je da je, $\mathrm{u}$ jednom takvom ambijentu, potreban nov model upravljanja rizicima baziran na ranom uočavanju svih rizika i proučavanju njihovog međusobnog uticaja, kao i proširen koncept upravljanja rizicima koji se bazira ne samo na izbegavanju, već i na korišćenju rizika. $S$ tim u vezi, kontrola rizika mora da bude svestranija. To, u osnovi, stvara ambijent za stabilnije poslovanje i bolju upotrebu raspoloživog kapitala.

Izloženi stavovi su razvijeni sa nastojanjem da ukažu na način izbora najpovoljnije tržišne alternative ulaganja. U navedenom izlaganju konstatovano je da slaba korelacija hartija od vrednosti smanjuje rizik bez smanjenja prinosa. Međutim, rastuća integracija nacionalnih tržišta, istovremeno smanjuje mogućnosti za ostvarenje pozitivnih efekata diversifikacije portfolija.

Finansijskim inovacijama i novim pristupima upravljanja rizicima investitori nastoje da smanje rizik i iskoriste šanse koje im pruža globalno finansijsko tržište. Efikasan sistem upravljanja rizicima podrazumeva da se jasno definišu strategije i politike upravljanja rizicima, kao i nosioci sistema upravljanja rizicima. Potrebno je definisati poslovne procese i procedure za identifikovanje, procenu, merenje i kontrolu rizika. Uz to, sofisticirani modeli obezbeđuju diversifikaciju rizika i procenu adekvatnog iznosa kapitala finansijskih institucija. Međutim, ne sme se izgubiti iz vida da modeli ne mogu biti zamena za čoveka. Stoga se predlaže rano upozoravanje otkrivanjem slabih signala, izrada alternativnih scenarija $u$ slučaju primene najboljeg scenarija, odnosno, konstruisanje drugih portfolija i u slučaju izbora optimalnog portfolija.

Navedeni modeli merenja rizika predstavljaju stabilnu i pouzdanu deskripciju stvarnosti. Međutim, zbog stalnog rasta sistemskog rizika, buduća istraživanja će zahtevati primenu proširenog koncepta upravljanja rizicima koji, pored konvencionalnog pristupa upravljanja rizicima, uključuje i proces sagledavanja interakcije različitih rizika. Globalna finansijska kriza pokazala je da prilikom sagledavanja stepena izloženosti rizicima nije dovoljno pažnje posvećeno kvalitativnoj dimenziji, tj. organizaciji, upravljanju, podsticajima, procesima i ljudima. To podrazumeva premeštanje pažnje sa traženja tehničkih slabosti 
modela upravljanja rizicima na povećanje fleksibilnosti u upravljanju rizicima, prepoznavanje važnosti psihološkog faktora koji izaziva promenu ponašanja tržišnih učesnika i sveobuhvatan pristup upravljanja rizicima. Nesporno, to bi doprinelo unapređenju upravljanja rizicima $u$ finansijskim tokovima današnjice.

\section{ZAHVALNICA}

Ovaj rad je deo interdisiplinarnog istraživačkog Projekta (br. 41010), koji finansira Ministarstvo nauke Republike Srbije.

\section{REFERENCE}

Back, E. K. (2010). Asset Pricing and Portfolio Choice. New York, NY: Oxford University Press.

Barucci, E. (2003). Financial Markets Theory: Equilibrium, Efficiency and Information. London, UK: Springer Finance.

Beder, S. T. (1995). VaR: Seductive but Dangerous. Financial Analysts Journal, 51(5), 12-24.

Belke, A., \& Schneider, J. (2011). Portfolio Choice of Financial Investors and European Business Cycle Convergence: A Panel Analysis for EU Countries. Empirica, November, 1-22, DOI: 10.1007/s10663-011-9181-4.

Blake, D. (2000). Financial Market Analysis. Chichester, England: John Wiley \& Sons Ltd.

Chapados, N. (2011). Portfolio Choice Problems: An Introductory Survey of Single and Multiperiod Models. New York, NY: Springer.

Chopra, V. K., \& Ziemba, W. T. (1993). The Effect of Errors in Means, Variances and Covariances on Optimal Portfolio Choice. Journal of Portfolio Management, 19(2), 6-11.

Crouhy, M., \& Robert, N. (2006). The Essentials of Risk Management. New York, NY: McGraw-Hill.

Đuričin, D. (2009). Kako iz ekonomije moralnog hazarda preći u ekonomiju inteligentnog upravljanja rizicima: Slučaj Srbije. Ekonomika preduzeća, 7-8, 259-283.

Eatwell, J. (1996). International Capital Liberalisation, The Impact on World Development. CEPA Working Paper Series
I, Working paper No. 1, Center for Economic Policy Analysis, $1-61$.

Fabozzi, F., \& Modigliani, F. (1996). Capital Markets - Institutions and Instruments. New Jersey, NJ: Prentice-Hall, Inc.

Hull, C.J. (2010): Risk Management and Financial Institutions. Boston, Massachusetts: Pearson Education, Inc.

Kim, J., \& Finger, C. C. (2000). A Stress Test to Incorporate Correlation Breakdown. Journal of Risk, 2(3), 5-19.

Konno, H., \& Yamazaki, H. (1991). Mean-absolute Deviation Portfolio Optimization Model and its Application to Tokyo Stock Market. Management Science, 37(5), 519-531.

Mandelbrot, B. (1963). The Variation of Certain Speculative Prices. The Journal of Business, 36(4), 394-419.

Markowitz, H. (1952). Portfolio Selections. Journal of Finance, 7(1), 77-91.

McEnally, W. R., \& Boardman, M. C. (1979). Aspects of Corporate Bond Portfolio Diversification. Journale of Financial Research, 1(1), 27-36.

Michaud, R. O. (1989). The Markowitz Optimization Enigma: Is "Optimized" Optimal? Financial Analysis Journal, 45(1), 31-42.

PD ISO/IEC Guide 73:2002. Risk Management Vocabulary. Guidelines for Use in Standards.

Rejda, E. G. (2008). Principal of Risk Management and Insurance. 10th Edition, Boston, Massachusetts: Pearson Education, Inc.

Ross, S. (1976). The Arbitrage Theory of Capital Asset Pricing. Journal of Economic Theory, 13(3), 341-360.

Rubinstein, M. (2002). Markowitz's Portfolio Selections: a fifty - year retrospective. Journal of Finance, 57(3), 1041-1045.

Schroeck, G. (2002). Risk Management and Value Creation in Financial Institutions. Chichester, England: John Wiley and Sons Ltd.

Segal, S. (2006). Value - Based Enterprise Risk Management: The Key to Unlocking ERM Potential. Corporate Finance Review, 10(4), 16-26.

Semmler, W. (2011). Asset Prices, Booms and Recessions. 3rd Edition, Berlin Heidelberg, Germany: Springer

Sharpe, F. W., Alexander, J.G., \& Bailey, J.V. (1995). Investments. Englewood Cliffs, New Jersey, NJ: Prentice-Hall, Inc.

Sharpe, W. (1964). Capital Assets Prices: A Theory of Market Equilibrium. Journal of Finance, 19(3), 425-442. 
Tumminelo, M., Di Matteol, T., Aste, T., \& Mantegna, R.N. (2007). Correlation Based Networs of Equity Returns Sampled at Different Time Horizons. The European Physical Journal B, 55, 209-217, DOI: 10.1140/epjb/e2006-00414-4.
Van Horne, C. J., \& Wachowicz, M. J. (1998). Fundamentals of Financial Management. New Jersey, NJ: Prentice-Hall, Inc.

Whitmore, G. A. (1970). Diversification and the reduction of dispersion: a note. Journal of Financial and Quantitative Analysis, 5(2), 263-264.

Primljeno 27. septembra 2012, nakon revizije,

prihvaćeno za publikovanje 12. decembra 2012.

Milena Jakšić je docent na Ekonomskom fakultetu Univerziteta u Kragujevcu. Izvodi nastavu iz nastavnih disciplina Osnovi ekonomije i Finansijska tržišta i finansijski instrumenti. Doktorirala je na Ekonomskom fakultetu Univerziteta u Kragujevcu, iz oblasti tržišta kapitala. Ključne oblasti njenog naučnog interesovanja su finansijski sistem i finansijska tržišta.

\title{
RISK MANAGEMENT OF PORTFOLIO SECURITIES
}

\author{
Milena Jaksic \\ Faculty of Economics, University of Kragujevac, Kragujevac, Serbia
}

Investment funds in different types of financial assets are motivated by investors' expectation to realize a profit. Since the expected return is not always certain, the investor is faced with a risk of his investment not giving results in accordance with the expectations. Therefore, the consideration of risk by which the concrete placement is hampered should not be neglected or left to intuition. An incorrect risk assessment can result in a lack of the expected return or a loss of a capital investment. The global financial crisis has indicated on the possible absence consequences of the comprehensive risk management, in other words, the inadequate perceiving of all the risks and their interdependencies. In this paper, the system of managing risks including their early identification, assessment, measuring and risk control is analyzed. At the same time, models providing an effective portfolio diversification in the function of reducing an investment risk have been analyzed. It is indicated that risk management requires the process flexibility without strongly relying only on mathematical models that failed to identify the growth of a systemic risk.

Keywords: risk management, diversification, portfolio, systemic risk 